\title{
THE SOVEREIGN, THE LAW AND THE TWO BRITISH EMPIRES $^{1}$
}

\section{IAN DUNCANSON*}

All political societies have peculiarities, and nothing special is to be concluded from the Anglophone focus of the present article. The theme here is that there was a schism between the first and second British empires, not in itself an original thought, as the paper makes clear. The first empire, as conceived by many historians, was an Atlantic empire governed by the British monarch and the Westminster legislature in the United Kingdom, and by the British monarch through his local representative, the colonial governor and the colonial assemblies. It appeared as a kind of confederation to many contemporaries, including Franklin and Washington, until as late as the mid-1770s. In each of the communities, the common law governed according to the customs of the people, subject to amendment by the appropriate legislature. The latter might be at London, Massachusetts or Philadelphia. For reasons outlined in the article, this system broke down when Westminster asserted ultimate sovereignty and the validity to override colonial assemblies and tax the colonies without their consent. The colonies objected and broke with Britain.

In Britain itself and in the remaining colonies, Westminster's assertion represented a new, stronger view of sovereignty, one in which law no longer even notionally reflected the slowly changing customs, habits and expectations of the governed. Instead, sovereignty represented the will of the sovereign. The legitimacy or validity of laws no longer referred to their content, or their conformity with a "balanced" constitution. Instead, the legitimacy rested in the pedigree of a law. To its practical question, 'is this a valid law?' the British imperial world was ready for the Benthamite answer. The latter was to remain culturally dominant for many decades, and still dominates the dry fields of legal positivism and conservative social science. Bentham asked 'is a law the sign of the volition of the sovereign?' Elsewhere, Bentham asserted that the content of the law bore no relation to its validity. This article examines this change from the earlier Whig thought which informed the American Revolution and what became of it.

Toutes les sociétés politiques ont des particularités, et il ne faut rien

1 Thanks to Jenny Beard for her incomparable still and calmness in a difficult time for me, and her encouragement and the loan of some of her ideas. A considerable debt for the space to write this article is owed to the UBC Law Faculty, which provided me twice with accommodation at Green College, office space in the faculty and wonderful library access; and particularly to Professors Susan Boyd and Clare Young. A deeper debt still is owed to Professor Pue at UBC, whose support for my research in general, although not for this piece in particular, sustained me through extraordinarily dark times in Australia. The Socio-Legal research Center at Griffith University, headed by Professor Richard Johnstone provided vital support and encouragement. Most of all I owe Judith Grbich, partner, friend, critic, and the person but for whom I would not have survived my eighteen months' illness.

* Research Associate, Institute of Postcolonial Studies, University of Melbourne; Adjunct Associate Professor, Sociolegal Research Centre, Griffith University 
conclure de spécial du fait que le présent article porte sur le monde anglophone. Le thème ici est qu'il y avait un schisme entre le premier et le deuxième empires britanniques, ce qui n'est pas en soi une pensée originale, comme l'indique clairement l'article. Le premier empire, tel que conçu par plusieurs historiens, était un empire atlantique gouverné par le monarque britannique et la législature à Westminster au Royaume Uni, et par le monarque britannique par l'entremise de son représentant local, le gouverneur colonial et les assemblées coloniales. Cela prenait l'apparence d'une sorte de confédération pour plusieurs contemporains, y compris Franklin et Washington, encore jusqu'au milieu des années 1770. Dans chacune des communautés, la common law gouvernait selon les coutumes du peuple, sous réserve d'amendement par la législature appropriée. Celle-ci pouvait se trouver à Londres, au Massachusetts ou à Philadelphie. Pour des raisons énumérées dans l'article, ce système a cessé de fonctionner quand Westminster a affirmé la souveraineté ultime et la validité de passer outre aux assemblées coloniales et de taxer les colonies sans leur consentement. Les colonies ont objecté et se sont séparées de la Grande Bretagne.

En Grande Bretagne même et dans le reste des colonies, l'affirmation de Westminster représentait une nouvelle conception, plus puissante, de la somveraineté selon laquelle la loi ne reflétait plus, même dans l'abstrait, les coutumes, les habitudes et les attentes des gouvernés, qui changeaient lentement. Plutôt, la souveraineté représentait la volonté du souverain. La légitimité ou la validité des lois ne se rapportait plus à leur contenu ou à leur conformité à une constitution «équilibrée». Plutôt, la légitimité reposait sur le pedigree d'une loi. À sa question pratique, «cette loi est-elle valable?», le monde impérial britannique était prêt pour la réponse de Bentham. Celle-ci devait continuer à dominer la culture pendant plusieurs décennies, et continue à dominer les domaines arides du positivisme juridique et de la science sociale conservatrice. Bentham demandait «une loi est-elle signe de la volition du souverain?». Ailleurs, Bentham a affirmé que le contenu de la loi n'avait aucun rapport à sa validité. Cet article examine ce changement par rapport à la pensée whig antérieure qui a inspiré la révolution américaine et ce qui en est devenu.

There can never be a single story. There are only ways of seeing. So when I tell a story, I tell it not as an ideologue who wants to pit one ideology against another, but as a story-teller who wants to share her way of seeing. ${ }^{2}$

These are the times that try men's souls. ${ }^{3}$

2 Arundhati Roy, An Ordinary Person's Guide to Empire (New Delhi, Penguin, 2005) at 14 [Roy, Empire].

3 Thomas Paine, “The Crisis Number 1," in Bruce Kuklick ed., Thomas Paine: Political Writings (New York: Cambridge University Press, 2000) at 41. 


\section{INTRODUCTION}

In 1950s midland England, a person receiving medical attention at home was "in bed under the doctor". Medics were positioned as masculine, whether or not they were actually men and as experts or authority figures like clerics, lawyers and policemen whose judgment was not to be questioned. Of course, patients suffer and die; sinners, losing litigants and criminals will pay the penalty. All will have their fate explained in a world that has not yet outgrown the hierarchy from which empires are conceived, by experts who, in a world of such empires, occupy a missionary position. Whoever heard of empires without missionaries: facedown, dominating, as the religions of the book require, the earth and all that therein is? Whoever heard of an imperial missionary who was not positioned, not only as masculine, but as a particular kind of masculine: a purer, stronger figure, one imbued with the authority to tell us who we really are or should have aspired to be? Corrupt or sexually promiscuous businessmen are roguish, in our representations, depending upon the harm done; a dishonest politician may delight with his or her subtlety; but for a police officer or lawyer taking bribes, or a sexually dallying medic, cleric or even academic, particular shock is reserved. It is because the latter are perceived to have a position of uniquely pure Authority in the fields they define, but we need to ask from whence that Authority came and by those who claim it and by those who submit to it. In Arundhati Roy's spirit, my article is about different approaches to the constitution of, and responses to, Authority. Hence, among other effects, this article explores the legality of law, while remembering that practical authority and abstract Authority make very different claims and often perform in very different ways.

The trying times, to which Tom Paine referred, ${ }^{4}$ were times in which Whig principles of self-government, by agreement in England, Scotland and America, (however limited to elite white men) - and Paine would have extended them to include women, First Peoples and Africans in America ${ }^{5}$ - were under a threat that Whiggery had been designed to avert. Paine, a plain Norfolk man who wrote brilliantly accessible political prose on the rights of people everywhere was no more a religious man than the aristocratically-connected Scot, David Hume. Though Hume was more conservative, both were deeply committed to intellectual fluidity and a fierce commitment to the tolerance of uncertainty and all it entailed in all spheres of human existence.

Through feminist and cultural studies scholarship, we have returned to that position. My paper is inspired by both that earlier, eighteenth century work and its twentieth century successors. Not surprisingly, in the US and now in Australia, the same positivism that drove the secondary literary literature on nineteenth century natural science, has resurfaced in the "culture wars" to which I will refer, to silence dissent, but, more importantly, as Locke pointed out, to elide the importance for progress of maintaining dissent and ways of dissenting. 


\section{THE PRESENT}

That het'rogenious thing, an Englishman:

In furious rapes and furious lust begot

Betwixt a painted Briton and a Scot

Whose gend'ring offspring quickly learned to bow

And yoke their heifers to the Roman plow

From whence a mongrel half-bred race there came

A True-Born Englishman's a contradiction,

In speech an irony, in fact a fiction. ${ }^{6}$

Defoe's "satyr" is a shrewd shot at those whose assertion of a pure-bred Englishness formed the basis for further claims to superiority over "lesser breeds without the law", as Kipling was much later to put it, ${ }^{7}$ and for the privileged destiny of this apparently special people. "The True-Bred Englishman" stands in a bathetic juxtaposition with the spirit of Kipling's "Recessional" across historical time. Defoe is an important contributor to the figuration of a kind of popular sovereignty in English (and after 1707, British) politics, but for the moment it is sufficient to notice his deflation of the arrogance of the English imaginary in its relation to "foreigners". The English represented by Defoe are of "mongrel" provenance, less pure-bred than a thoroughbred Turkish horse, the outcome of successive invasions, immigrations and endless sexual unions, welcomed or not and, more recently, of refugees:

Religion, God we thank thee, sent them hither,

Priests, Protestants, the Devil and all together

Of all professions and of every trade

All that were persecuted or afraid.

Such miscelleneaty leaves us no room for boasting of ancestors; instead, tolerance and "personal virtue only make us great".

In this context, it is disturbing to read three centuries later a 2006 article reflecting on the attitudes of many British-born Muslims to the country of their birth and its possible basis in British jingoism overseas and exclusionary practices at home. The well-known Guardian columnist, Timothy Garton Ash, relates the "shocking" finding in a recent British opinion poll in northern England that many younger Muslims identified with their religion more closely

6 Daniel Defoe, “The True-Born Englishman” in P.N. Furbanks and W.R. Owens, eds., The TrueBorn Englishman and Other Writings (London: Penguin Books, 1997) at 34-35.

7 Rudyard Kipling, "Recessional" (1897). The poem reflects on the global pre-eminence of the British Empire and sees the avoidance of hubris in recognition of God's role in the accomplishments of "Thy people, Lord". God is "with" the English, but will judge them according to their acknowledgement of his divine assistance.

8 It needs to be emphasized, that the English, be they Scottish or whatever (see later), never became a Volk; citizens of a patrie.

9 Timothy Garton Ash, "It's shocking but it's true" Guardian Weekly (18 August 2006) 13. See also Gary Younge, "How to fight reactionaries” Guardian Weekly (25 August 2006) 13. 
than with their citizenship and that they would prefer to live under Shari'ia, rather than under English or Scots law. The immediate context into which Ash places these findings is the discovery, early in the police investigation, that the mid-2005 London Transport bombings, and the attempts to sabotage civilian airliners flying out of Heathrow a year later were not the work of overseas nationals sent covertly by some unidentified middle eastern state, but of well-educated second generation UK citizens who were Islamic.

Ash reports a litany of complaints which partly explain this disaffection, articulated mainly by middle class Muslims and responded to by many more, if one thinks of the bombings and attempted bombings in London, of persistent discrimination on religious or ethnic grounds. Tarique Ghaffur, Assistant Commissioner of the London police, for example, is quoted complaining of discrimination not only against himself, but also of the alienating effects on British Muslims of so-called "racial profiling" common in the surveillance practices of the predominantly white British police force ${ }^{10}$ as well as prejudicial tabloid representations of "people of middle-eastern appearance", tragically to embrace an olive-skinned young man from Brazil, shot seven times at close range by police, whilst he was innocently travelling to work on an Underground train.

The other context for Islamic disaffection, Ash suggests, is the skimped and botched attempt to rehabilitate Afghanistan and the contemptuously transparent lies used to justify the Anglo-US invasion of Iraq. The ideological representation of the "West's" civilizing mission to brown people was provocation enough. However, the obscene underside of Western civilization surfaced in the form of indiscriminate detentions, humiliations and torture, predominantly of Muslims world-wide, resulting in suspicion, disbelief and ultimately the abrogation of the loyalty to their land of settlement by many younger Muslims.

Evident in the regression from the neo-colonialism of the mid-twentieth century discourse of "development" to the old-style colonialism in which white-led armies invade and occupy the territories of brown people, is the effect of imperialism on the government of the imperialists themselves. ${ }^{11}$ Imperial powers have never, as Cooper and Stoler write, launched themselves fully-formed upon an empty place, or a place to be emptied and its culture and its politics to be re-inscribed. ${ }^{12}$ In their pursuit of a "war on terror", political leaders in the US and the UK have themselves practiced terrorism, Arundhati Roy argues, flouting the very due processes of law and the Geneva Convention on the treatment of prisoners of war. In opposing authoritarianism, the leadership of the US and the UK have, however,

10 Riazat Butt and Vikram Dodd, "Terror Laws Alienate Muslims" Guardian Weekly (11 August, 2006) 9.

11 Roy, Empire, supra note 2 at 14; Matthew Yglesias, "Torture Incorporated" The Age (2 October 2006) syndicated from American Prospect details the proposed retrospective US War Crimes statute, quoting Jack Balkin, Professor of constitutional law at Yale: in cases deemed relevant, habeas corpus will be unavailable and the executive will be the authoritative interpreter of the meaning of the Geneva Convention.

12 Frederick Cooper and Ann Laura Stoler, "Foreword" in Frederick Cooper and Ann Laura Stoler, eds., Tensions of Empire: Colonial Cultures in a Bourgeois World (Berkeley: University of California Press, 1997). 
adopted many of its forms, and Australia, a minor player, and Canada, not a direct player at all, have colluded - proscribing certain organizations and books, punishing disapproved intentions, encouraging detention without trial, multiplying proactive surveillance of innocent citizens in case they are not or may at some stage cease to be innocent and inuring citizens to the presence of a combat-armed military on the streets. Roy writes from India, but a little world-travelling shows us troops with automatic weapons at, for example, Waterloo, Changi and $42^{\text {nd }}$ Street Stations. What those troops can do when a suicide bomber/martyr acts, is die, which they are doing in large numbers in Baghdad, the most militarized of cities. But we do not have to be reminded of their symbolic significance for the status of our citizenship. Their M16s, Steyrs and Uzis are not the lances of the Athenian phalanx; they are of the 'them', not of the 'us'. We pay, of course, but others decide and divide us.

Not unconnected from this division in most western countries, welfare benefits, including those to the disabled, are subject to strict work tests, with eight-week withdrawal of benefits in the event of perceived failure of compliance. This practice invests enormous discretionary powers in privatized welfare providers and relegates "failures" to seek charity. Respected agencies, such as the Salvation Army, have withdrawn their cooperation with this scheme. Asylum-seekers, deliberately and inaccurately demonized, are made to loom large as threats, linked in vague ways with a terrorist menace whose nature is itself vague, but which could encompass any thoroughgoing attacks on the new status quo. A cowed, ignorant, fearful populace, living under nineteenth century freedom-of-contract industrial relations laws, creates an ideal environment for international capital: for Enron to assist the privatization of Indian electricity and eliminate cross-subsidies between urban and rural users, and for Halliburton and Bechtel, with close links to the White House, to claim rebuilding rights in Iraq. ${ }^{13}$

\section{THE PAST SPECIFIC}

I now return to history not as an Americanist or a Jeffersonian but to point to a different program for a future. The question has partially been, 'what of the Whigs, from which Jeffersonianism partly sprang and where their politics pointed?' My view is that it pointed to something not peculiar to the UK, but usefully summarized there as "Butskellism". Canadian historians have drawn our attention to the fact that "nations", of which we have lately heard much, do not exist, save in the minds of bureaucrats and politicians who wish to send the poor to war, often, for ends that are unclear to many outside corporate boardrooms.

But history, whilst it cannot escape mythology, must certainly try to escape pageantry. If it is to be useful it must also be specific whilst being careful not to co-opt everyone in a specific time frame into its specific truths - it will by now be evident from recent historiography that this is necessarily history from the present. Since E. H. Carr's pioneering work, ${ }^{14}$ it is necessary

13 Roy, Empire, supra note 2 and Arundhati Roy, The Algebra of Infinite Justice, rev. ed. (New Delhi: Penguin Books, 2002).

14 Edward Hallett Carr, What Is History?, 3d ed. (Basingstoke: Palgrave Publishing ,2001) 
to ask, what other kind of history can there possibly be ${ }^{15}$ Both thinkers and the reactionary revisionists of progressive histories are enthusiastic to prove that there can be none, whilst constructing narratives from widely differing political perspectives. ${ }^{16}$ The specific historical invitation I want to accept takes its rise from the questions Defoe asks in the England of the early eighteenth century, and perhaps has some relevance to the plight respectively of those whose religion derives from Islam, and those whose religion inclines them to national exclusiveness, but who have to inhabit the same world and often the same territory. It takes us into issues of identity and law and into what creates obligation to both government and law, as well as issues of what is taken to constitute legality from normative discourses, when and by whom.

A contrast made by Hannah Arendt in her work On Revolution between the American and French revolutions ${ }^{17}$ suggests itself. Pessimistically concluding that "in America no less than in France" the "spirit (of participation in government) that had been manifest in the Revolution" was soon condemned to "oblivion," 18 she distinguishes the original American and French aspirations. Coming out of a Whig tradition acutely suspicious of any government not subject to checks and balances, elite white men in America had to begin with little use for doctrines of sovereignty. In France,

[n]ational sovereignty, that is, the majesty of the public realm itself as it had come to be understood in the long centuries of absolute kingship, seemed in contradiction to the establishment of a republic. In other words, it is as though the nation state, so much older than any revolutions, had defeated the revolution in Europe even before it had made its appearance. ${ }^{19}$

Little attention was paid in Europe to Montesquieu's notion of the separation of powers, drawn in part, as he thought, from observations of Whig Britain:

...the downfall of the monarchy did not change the relationship between the ruler and the ruled, between government and the nation, and no change of government seemed to heal the rift between them. The revolutionary governments, in this respect not unlike their predecessors, were neither of the people nor by the people, but at best, for the people. ${ }^{20}$

At stake here are the ideas of contingency and located responsibility. Governmental sovereignty, as Arendt sees it, assumes a meta-legal sovereign, an

15 Keith Jenkins, Re-Thinking History (London: Routledge Publishing, 1991); Alun Munslow, Deconstructing History (London: Routledge Publishing, 1997); Ann Curthoys and John Docker, Is History Fiction? (Sydney: UNSW Press, 2006).

16 See Stuart Macintyre and Anna Clark, The History Wars (Melbourne: Melbourne University Press, 2003); Robert Manne, ed., Whitewash: On Keith Windschuttle's Fabrication of Aboriginal History, (Melbourne: Black Ink Agenda, 2003).

17 Hannah Arendt, On Revolution (London: Penguin Books, 1973) [Arendt, Revolution].

18 Ibid. at 132.

19 Ibid. at, 24.

20 Ibid. at 74. 
agency which acts through law, but is able to prescribe the limits of law and inscribe on the community subject to it a state of emergency: the exception in which law no longer applies. Confronted by such an agency, the citizen can enjoy the freedom experienced by Adolf Eichmann at the Wannsee conference which designed the Final Solution, the industrialized mass murder of the Jews.

Now he could see with his own eyes and hear with his own ears that not just Hitler, not only Heydrich or the "sphinx" Muller, not just the SS or the party but the elite of the good old civil service were vying and fighting with each other for the honor of taking the lead in these "bloody" matters. "At that moment I sensed a kind of Pontius Pilate feeling for I felt free of guilt". Who was he to judge? Who was he "to have his thoughts in this matter"? Well, he was neither the first nor the last to be ruined by modesty. ${ }^{21}$

There is more in this notion of meta-legal agency than the proposition that in order to be able to delineate the boundary of something one must be outside it. To see that this is a circle or a sphere or a triangle, classical geometric logic requires that, conceptually, at least, an external point of view is necessary. But the sticking point with the Whigs, and following them, Jefferson, (and pace Hobbes) is that politics was not geometry, and one is never outside. There is no totality or finality, only agreement, disagreement and dialog. In France, Arendt writes, sovereignty lay with the people, expressed in the general will, as in Rousseau's reformulation of Louis XIV's famous "L'Etat, c'est Moi". In identical fashion, the premise required an embodiment, a distillation, in order to be made meaningful, one which it accomplished through Robespierre and, in his endless quest for purity and an end to selfinterest, to the Terror. Arendt quotes a speech of Hitler's: "All that you are, you are through me; and all that I am I am through you". But, as she writes, "this idea has always presupposed someone in command who thinks and wills and then imposes his thought and will on a thought- and will-deprived group". ${ }^{22}$ Totalitarianism succeeded in commanding the imagination, the obligatedness, of atomized masses, she thought, because its propaganda combined the convictions that anything is possible (and the Thatcherite, "we must think the unthinkable" comes appallingly close) with a notion of inevitability (again, one thinks of the "There is no alternative" of the Thatcher era economic reforms). Mass liquidations and absurd economic plans were the Stalinist route to the inevitable victory of the working class, just as the Holocaust and the unsustainable project of world conquest became the route to the inevitable triumph of the Aryan volk. ${ }^{23}$ Neither Nazism nor Stalinism is a likely outcome in the "core" Euro-American states, although they have

21 Hannah Arendt, Eichmann in Jerusalem: A Report on the Banality of Evil (London: Penguin Books, $1977)$ at 114 [emphasis in original].

22 Hannah Arendt, The Origins of Totalitarianism (New York: Harcourt Brace Publishing, 1976) at 325 [Arendt, Totalitarianism].

23 Margaret Canovan, Hannah Arendt: A Reinterpretation of Her Political Thought (Cambridge: Cambridge University Press, 1992) at 75. 
undoubtedly moved away from the ideal of constituting "an agreement of the people" However, they cannot absolve themselves from having created not dissimilar regimes elsewhere, ${ }^{24}$ sometimes for "security" purposes, sometimes for no apparent purpose. Ex-CIA colonel, John Stockwell, was in Africa for six years, before coordinating PR for the Apartheid-era alliance between the US and South Africa in Angola:

\begin{abstract}
What I got out of these six years was a sense that nothing we were doing in fact defended US national security interests... we were doing things because we were there... bribing people, corrupting people... we didn't have many national security interests in Bujumbura, Burundi. ${ }^{25}$
\end{abstract}

Destabilizing a possibly rich mineral region was doubtless not intended to result in the genocidal outcome in neighbouring Rwanda, whose ethnic composition is similar, but it is unlikely to have helped.

Arendt traces the occluded projections of natural necessity from within the polity of dictatorships and those who support them to the French Declarations of the Rights of Man and Citizen in the1790s. Unlike the Americans, who, at least to begin with, qualified their appeal to inalienable human rights with a crucial "we hold - these rights inalienable" (and actually, to emphasize the point, the famous Declaration refers to "unalienable" not "inalienable" rights ${ }^{26}$ the French appealed to an abstract humanity. But what, asks Arendt, ${ }^{27}$ in a question echoed by Giorgio Agamben ${ }^{28}$ and by Costas Douzinas, ${ }^{29}$ is abstract humanity? Where is it located? How can an abstract concept live? What are bare human rights? What is a bare human? In what might be considered the most sophisticated and articulate swan-song of Whig politics, Edmund Burke responded to the French Revolution:

I cannot stand forward and give praise or blame to anything which relates to human actions and human concerns on a simple view of the object as its stands stripped of every relation, in all the nakedness and solitude of metaphysical abstraction. Circumstances (which with some gentlemen pass for nothing) give in reality to every political principle its distinguishing colour and discriminating effect. The circumstances are what render every civil and political scheme beneficial or noxious to mankind. ${ }^{30}$

24 A Google search reveals a plethora of information about US involvement in the Pinochet dictatorship and that regime's policy of torturing opponents. The secret police chief was, apparently, a CIA "asset".

25 John Stockwell, "The Secret Wars of the CIA" The Other America's Radio (10 October 1987).

26 Arendt, Revolution, supra note 15 at 193; The spirit of "E Pluribus Unum" was supplemented under Eisenhower by "one nation under god" and by fundamentalist Bush disciples, for whom "US freedoms are "not the grant of any government or document but our endowment from God"': US Attorney-General Ashcroft, quoted in Roy, Empire, supra note 2 at 54.

27 Arendt, Totalitarianism, supra note 22 at 298.

28 Giorgio Agamben, State of Exception (Chicago: University of Chicago Press, 2005).

29 Costas Douzinas, The End of Human Rights (Oxford: Hart Publications, 2000).

30 Edmund Burke, Reflections on the Revolution in France (London: Dent Publishing, 1910) at 6, [author emphasis]. 
In the tradition of Locke and Shaftesbury, whatever his differences from them, Burke emphasizes the artificial nature of social order and of the work necessary to maintain it. The constitution - any constitution - is not, for him, an abstract set of principles in a hierarchy within which legitimacy is traced without regard for content. This construction would lead us to an agency paradoxically constituted by law, constituting law, yet at the same time outwith the law. For Burke, everyone is within the constitutional embrace, each subject is in his terms a "life-renter", inheriting his share and bequeathing it, meanwhile adapting it as best $\mathrm{s} /$ he can during her/his tenure to changes in circumstances or the modes of life or beliefs of the people. Bruce argues that "[a] good practical constitution..." is one in which, "the grand secret has been found of reconciling a government of real energy for all foreign and domestic purposes with the most perfect security to the liberty and safety of individuals." 31 In the shadow of this understanding of government, reasonable expectation guides custom in discerning the operation of the constitution, hence the "apparent omnipotence" of the King in Parliament would need forbearance in relation to the American colonists. ${ }^{32}$

\section{TWO EMPIRES AND THE AUTHORITARIAN INF(L)ECTION}

Arendt's distinction between the American inheritance from Whig Britain, as Americans had interpreted it by the 1750 s, is suggested by a century and more of reflections on the changes and implications of the British Empire. At least since Seeley's work, the idea of two empires has been familiar. In his "expansion of England", ${ }^{33}$ the first empire, in America, lost when conceived and treated as a possession, was followed by the second, a white empire of "Greater Britain". Seeley feels that this second empire may one day be a United States of Greater Britain, bound together by loyalty and a shared heritage of representative institutions and the common law rather than by Westminster sovereignty. Seeley argues that the US itself in 1884 has many of the reassuring characteristics of this heritage: politically independent, the future of Anglophone world supremacy, and the natural destination of British emigrants. India, by contrast, is indescribably other: a chaotic and largely unprofitable burden that was almost accidentally rescued by the British from the anarchy of post-Mogul degeneracy. Contrasting the Indian Empire with what he is prepared to term "the colonies", Seeley expresses the hope that some benefit might accrue to its inhabitants, who may learn from Britain the ways of lawful government. This line of reasoning has served as the pedagogical justification for most nineteenth century imperial rule of

31 Edmund Burke, cited in James Coniff, "Burke on Political Economy: The Nature and Extent of State Authority" (1987), 49 The Review of Politics 490 at 499.

32 Edmund Burke, "Speech on Moving his Resolutions for Conciliation with the Colonies, House of Commons March 22, 1775" in Peter Stanlis, ed., Edmund Burke: Selected Writings and Speeches (Washington DC: Regenery Publishing, 1963) at 176.

33 John Robert Seeley, The Expansion of England (London: Macmillan Publishing, 1898); Vincent Harlow, The Founding of the Second British Empire, 1763-1793, (London: Longmans Green and Co., 1964) vol.2 is a more uncompromising exponent of the concept. 
brown people, subsequent discourses of "development"34 and ultimately, if we follow Roy, the Middle Eastern ground-zero of $21^{\text {st }}$ century Iraq. ${ }^{35}$

Peter Marshall concedes that there is a connection between an empire lost, and an empire gained that concerns us if we want to understand law and legality and their relationship with the nation and the social in the manner recently recommended by Thornton and others. ${ }^{36}$ The question for the midto late eighteenth century, as Marshall summarizes it, was this:

[w]ere the British to be part of a predominantly Atlantic empire in which they would be primus inter pares, or were they to rule over a polyglot worldwide empire, most of whose peoples were clearly subject peoples? ${ }^{37}$

The Atlantic empire was conceived as an association of free British settlers living under common law, modified by assemblies of representatives that sprang up, if Seeley is to be followed, as a manifestation of English freedom and instinct for self-government. ${ }^{38}$ This seaborne empire of commerce, as opposed to the Roman empire of territorial acquisition, acquired a rosy gloss. For Americans, this gloss wore thin in ways that reveal how elite white people were thinking about the nature of government and laws, at least as they applied laws to themselves although not to the Africans they enslaved, or to the first peoples whom they brutally dispossessed. ${ }^{39}$ Custom, and the representative recollection and modification of it in the participatory activity of government at a number of levels, was not expected to have the Teutonic antiquity insisted upon by Freeman. ${ }^{40}$ In contrast, the customs, of which E.P. Thompson writes, ${ }^{41}$ were realistically regarded as underwriting the legitimacy of law originated in form from the county and seigniorial courts of the Middle Ages, where the suitors, or representatives of the lord's tenants, would assemble to argue and determine the application of custom to specific events. ${ }^{42}$ The editor of Matthew Hale's History of the Common Law of England,

34 Jenny Beard, The Political Economy of Desire: International Law, Development and the Nation State (London: Routledge-Cavendish, 2007).

35 Growing up in Kerala, under the first democratically-elected government in the world, in the era of Viet Nam, Roy tells of how she identified with the naked little Vietnamese girl, perhaps the most famous of the early napalm war crimes. Would she, Roy asked herself, be the next "slope" or "geek" freed by US terror-bombing of civilians?

36 Margaret Thornton, "The Dissolution of the Social in the Legal Academy" (2006) 25 Australian Feminist Law Journal 3

37 Peter Marshall, Making and Unmaking of Empires: Britain, India and America 1750-1783 (New Delhi: Oxford University Press, 2005) at 379.

38 See David Armitage, The Ideological Origins of the British Empire (Cambridge: Cambridge University Press, 2000); David Armitage and Michael Braddick eds., The British Atlantic World (Houndmills, U.K.: Palgrave Publishing, 2002)

39 For example, Bernard Bailyn, Atlantic History: Concepts and Contours (Cambridge: Harvard University Press, 2005).

40 Edward Freeman, The Growth of the English Constitution From the Earliest Times (London: Macmillan Publishing, 1894)

41 E.P. Thompson, Whigs and Hunters: The Origin of the Black. Act (London: Allen Lane Press, 1975) at 10; E.P. Thompson, Customs in Common (London: Merlin Press, 1991).

42 Rodney Hilton, Class Conflict and the Crisis of Feudalism: Essays in Medieval Social History, rev. ed. (London: Verso Press, 1990); Robert Palmer, The County Courts of Medieval England, 1150- 
published posthumously in 1713, 1716 and 1739, writes that for Hale,

authority did not inhere in reason and in the political sovereign who personifies reason and actualizes its power to secure peace and civilization. Those potentates must share authority with the subrational forces that make us communal animals... ${ }^{43}$

Subsequent historians, transfixed by the legal positivists, have noted Blackstone's observation that since the 1688 Revolution, Parliament, "being the place where that absolute despotic power which must in all governments reside somewhere, is entrusted by the constitution of these kingdoms." 44 They have left without serious comment his repetition of a contemporary commonplace: "no human laws are of any validity if contrary to (natural law); and such of them as are valid derive all their force and all their authority mediately or immediately from this." ${ }^{45}$ In his discussion of Locke's "right of resistance" to established authority, Blackstone's denial of any such a right was not the refusal of a long-discredited doctrine. Written before the Revolution in opposition to the likely succession of Charles II's autocratic and Catholic brother, James, the Second Treatise remained a radical and influential text. Ashcraft has shown, whilst its author was satisfied with the removal of James II by the Revolution, he was unconvinced that James' successors, William and Mary, had met the Revolution's objectives. ${ }^{46} 1688$ provides, a contemporary wrote to Locke before his return from Holland, and whence he had escaped because of his opposition to James' accession to the throne,

[a]n occasion not only of mending the government, but of melting it down and making all anew, which makes me wish you were there to give them a right scheme of government, having been infected by that great man, Lord Shaftesbury. ${ }^{47}$

After the event, conservatives opposed the revolution, Ashcraft argues, and many radicals were disappointed and perhaps disaffected. Blackstone's refusal of Locke trod a fine line with its seldom-observed qualification, "so long as the English constitution lasts". ${ }^{4}$

My argument has been that, whatever its hypocrisies, blindnesses and other failings, Whiggism justified some of Thompson's limited praise: its very

1350 (Princeton: Princeton University Press, 1982); John P. Dawson, A History of Lay Judges (Cambridge: Harvard University Press, 1960).

43 Charles Gray, "Introduction" in Sir Matthew Hale, The History of the Common Law of England, ed. By Charles Gray (Chicago: University of Chicago Press, 1971) at 34.

44 William Blackstone, Commentaries on the Laws of England (Oxford: Clarendon Press, 1765) vol. 1 at 156. And by whom? Can the Lockean skeptic not be contained? As we shall see, s/he cannot [Blackstone, Commentaries].

45 Ibid. at 41.

46 Richard Ashcraft, Revolutionary Politics and Locke's "Two Treatises of Government" (Princeton: Princeton University Press, 1986).

47 Lady Mordaunt, quoted in Peter Laslett, "Introduction" in John Locke, Two Treatises of Government, ed. By Peter Laslett (New York: Signet Publishing, 1965) at 58. Lady Mordaunt was referring to Locke's patron, the $1^{\text {st }}$ Earl of Shaftesbury.

48 Blackstone, Commentaries, supra note 44 at 157. 
corruption saving its subjects from the excesses of European Absolutism. Its bloody penal code was much mitigated in practice and unruly opposition short of outright rebellion ${ }^{49}$ was frequently accommodated. One important question, which I have addressed in part elsewhere, is how this - for the time - unusually benign state of affairs came about. ${ }^{50} \mathrm{~A}$ second question relates to its apparent demise and equally apparent replacement with, in F.R. Leavis's words, "technologico-Benthamism": an authoritarianism that led to a perhaps premature break with America and the increasingly racist contempt that characterized British relations with its Indian empire.

\section{CONSPIRACY THEORIES}

The answer to the first question, "how did the relatively benign Whiggery that underlies much modern constitutionalism come to be?' is difficult to frame without recourse to the notion of conspiracy. For eight decades prior to the 1688 Revolution, the isles had been governed by the Stuart dynasty (properly spelled Stewart, since they were descended from the stewards of the previous Scottish dynasty, an irony in view of their later claims). Bequeathed the English throne by Elizabeth, the Stuarts acted on the assumption that they governed by the grace of God. "Empire" was "a term particularly favoured by Henry VIII after his breach with Rome... and called to mind the relative isolation of England... rather than its dominion over foreign territories." ${ }^{51} \mathrm{It}$ was connected to a particular view of what sovereignty connoted: not simply a realm not subject to authority from without, but a ruler not subject to authority from within. "A coterie of royal legists and rhetoricians (who) appropriated the exalted concepts associated with the princely rule by court humanists in High Renaissance Italy" made possible an English "court humanism" in the context of which Henry could claim, even in 1515, that "kings of England have never had any superior but God himself"; later, "we of our absolute power be above the law". 52

James VI/I, Elizabeth's successor, was much taken with the Tudor imperial idea, referring to his post-1603 dual monarchy as "Greate Britainne's imperial crown" or the "Empire of Greate Brittaine" ${ }^{53}$. What distinguishes the Stuart monarchy is the attempt by its members to unite four peoples of two principal

49 Douglas Hay, "Property, Authority and the Criminal Law" in Douglas Hay et al, eds., Albion's Fatal Tree (London: Allen Lane Press, 1975); John Brewer and John Styles eds., An Ungovernable People: The English and their law in the Seventeenth and Eighteenth Century (New Brunswick: Rutgers University Press, 1980); Kathleen Wilson, The Sense of the People: Politics, Culture and Imperialism in England, 1715-1785 (Cambridge: Cambridge University Press, 1995); Kathleen Wilson, The Island Race: Englishness, Empire and Gender in the Eighteenth Century (London: Routledge Publishing, 2003).

50 Ian Duncanson, "Scripting Empire: The Englishman and Playing for Safety in Law and History" (2000) 24 Melbourne U.L. Rev. 952; Ian Duncanson, "Law as Conversation" in Ann Orford, ed., International Law and its Others (Cambridge: Cambridge University Press, 2006).

51 Nicholas Canny, "The Origins of Empire" in Nicholas Canny, ed., The Oxford History of the British Empire (Oxford: Oxford University Press, 1998) vol.1 at 1.

52 Brendan Bradshaw, "The Tudor Reformation and Revolution in England and Wales: The Origins of the British Problem" in Brendan Bradshaw and John Morrill, eds., The British Problem 15341707: State Formation in the Atlantic Archipelago (London: Palgrave Macmillan Publishing, 1996) at 52.

53 Canny, supra note 51. 
islands into one political entity. ${ }^{54}$ This political entity then attempted to establish "plantations" in North America whilst maintaining the Tudor doctrine of the sovereign as possessing untrammelled authority both within and outside the realm. The Jesuit, Salomonio, concluded that a sovereign, whilst superior to each of his subjects individually, is inferior to them collectively, and his fellow Jesuit, Suarez, insisted in the early seventeenth century, that there is a right of resistance to a monarch where "it becomes necessary for the preservation of the commonwealth itself." 55 These ideas "cut right across the doctrine of the divine right of kings enunciated by James in his 'Trew Law of Free Monarchies', ${ }^{\prime 56}$ which formed the foundation of his conception of the state and his divine right to rule it. In all European theology and political theory of the time, the basis of authority was both mysterious and controversial, except to those who claimed to wield it in an untrammelled form according to James' text. This text followed the traditional European kingly formula, "Kings are not only God's lieutenants on earth, but even by God himself are called Gods... Kings exercise a manner or resemblance of Divine power on earth." ${ }^{57}$ Suarez, a "monster" according to James, had his writings publicly burned in London by Royal decree. ${ }^{58}$ "A lawfull good king, having received from God the burthens of office, whereof hee is accountable" acts according to law, "yet hee is not bound thereto but by his good will". The sovereign sits "upon God his throne on earth." 59

"Doe not meddle with the main points of government, that is my craft, I must not be taught my office," James instructed Parliament in 1609, ${ }^{60}$ adding some years later in Star Chamber that his judges are his delegates, and that he retains the right to interfere "if your interpretation be such that other men which have logic and common sense understand not." ${ }^{91}$ By a tradition traceable to a text often attributed to the thirteenth century writer, Bracton, "quod Rex non debet esse homine, sed sub Deo et lege", kings are subject to none but God and the law. Further, "the king in his own person cannot adjudge any case betwixt party and party... cannot take any case out of his courts

54 Jane Dawson, "Anglo-Scottish Protestant Political Culture and Integration in $16^{\text {th }}$ Century Britain" in Steve Ellis and Sarah Barber, eds., Conquest and Union: Fashioning a British State, 1485 1725 (London: Longman Green and Co., 1995).

55 Quentin Skinner, The Foundations of Modern Political Theory, (Cambridge: Cambridge University Press, 1980) vol. 1 at 178.

56 Michael MacCraith, "The Gaelic Reaction to the Reformation" in Ellis and Barber, supra note 54, at 150 .

57 Glenn Burgess, Absolute Monarchy and the Stuart Constitution (New Haven: Yale University Press, 1996), argues that the Stuarts were regarded as bound to rule according to law, but takes the Hobbesian line that there is no secular remedy if they do not. Only Whigs, he thinks, could see this as absolutism. But see Julian Franklin, "Introduction" in Julian Franklin, ed., Bodin on Sovereignty (Cambridge: Cambridge University Press, 1992) at 26, who attributes Jean Bodin's belief that a sovereign not subject to a right of resistance is nevertheless governed by law to "optimism".

58 James VI, "A Remonstrance for the Right of Kings and the Independence of Their Crownes Against an Oration of the Most Illustrious Card of Perron, Pronounced in the Chamber of the Third Estate" in Charles McIlwain, ed., The Political Writings of James I (Cambridge: Harvard University Press, 1918) at 169. On the burning, see Charles McIlwain's "Introduction" at 64.

59 James VI, "Basilikon Doron" in McIlwain, ibid. at 18.

60 McIlwain, supra note 58 at 306.

61 Ibid. at 326 
and give judgments upon it himself... judgments are always given per curiam and judges are sworn to the laws and customs of England." To this, James' reaction was predictable. According to an observer, "he fell into that high indignation as the like was never known in him looking and speaking fiercely and with bended fist." ${ }^{\text {. }}$

The position of the meta-legal sovereign ultimately competent to decide upon the exception: the law's limit, as Carl Schmitt and Agamben were later to put it, could scarcely be clearer put than in twentieth century discussions of fascism. At the time, it was hard for contemporary lawyer, Edward Coke, to seek secure refuge behind the institution of the common law, prestigious and emblematic as it was, since judges were appointed and held office during the King's pleasure, a situation not ended until the Settlement Act of $1701 .^{63}$ Coke's other resort was more secure. If the King did not summon Parliament, he would not receive supply; if he did summon them, they might well "meddle with the main points of government". James lost his temper when reminded of the limits his subjects placed on his sovereignty; his son Charles lost his head in 1649.

The events of the seventeenth century revolutions, and of the impossibility of avoiding the disadvantages of the simple form of Europeanstyle Absolutism by substituting legislative sovereignty, are well-enough documented. During the century or so following Charles' execution, a number of means were attempted both to secure the state from its internal and external enemies, or to protect property, and to safeguard trade and credit. One means, perhaps less thoroughly discussed by contemporaries but offering some continuity with analysis of more recent times, was the constitution, not of the state but of the subject. ${ }^{64}$ Hume provides a lens and a methodology. His account of the seventeenth century struggles that encompassed the British archipelago has much in common with that of others.

The religio-political impasse takes on the character of a dialectic in which the absolutist pretensions of the Stuart monarchy and its supporters had increasingly tended toward Catholicism, understood in Hume's terminology as "superstition". In opposition to it were the myriad evangelical protestantisms, labeled "enthusiasm" by Hume, ${ }^{65}$ which were the only forces at hand with the political energy or appeal to confront established despotism. The aptly-named "Convention", Parliament provided a latitudinarian synthesis in which it may

[j] ustly be affirmed without any danger of exaggeration that we, in this island, have enjoyed, if not the best system of government,

62 William Holdsworth, A History of English Law (London: Methuen Press, 1945) vol. 5 at 430.

63 See Howard Nenner, By Colour of Law: Legal Culture and Constitutional Politics in England 1660-1689 (Chicago: University of Chicago Press, 1978).

64 I am regrettably unable to put this into the language of modern European philosophy, since the Hegelians and others took from the Scots and their borrowings from Locke, Shaftesbury and their borrowings in turn from the civil war writers whose writings I have no space to discuss. We could no doubt extend our discussions to Marcus Aurelius and his sources, but to extend respect to my readers, I can work only with the sources with which I have some familiarity. I hope that in what follows, my meanings will become clear.

65 David Hume, "Essay X, Of Superstition and Enthusiasm" in Eugene F. Miller, ed., Essays Moral, Political and Literary (Indianapolis: Liberty Classics, 1983) at 74, 76. 
at least the most entire system of liberty that was ever known amongst mankind. ${ }^{6}$

A question seldom asked is why David Hume, the leading philosopher and historian of his time, should have devoted so much of his time to reflecting on what were predominantly issues of English history and the politics of English constitution. Equally relevant might be the questions, 'why did the English language as the medium of higher education emerge in Glasgow, with Francis Hutcheson?' or 'why did English studies emerge with Adam Smith somewhat later in the same city? ${ }^{367}$ In part, the answer must be that Scotland had free elementary education and affordable universities that differed from the upper class finishing schools which Oxford and Cambridge were rapidly becoming. The emergence of English studies also related to the 1707 Act of Union: the basis of the United Kingdom, and to the aspirations which the Act led the Scots to entertain. As the larger, more powerful and commercially developed country, England had much to offer, but only if political stability and the twin virtues of liberty and property remained secure. Hume's account of their emergence suggests some doubt that the English unassisted could accomplish this.

Lemmings' remarks may even suggest a certain prescience in Hume's conclusions. Lemmings writes that there was "a widespread popular subscription to the quasi-libertarian and egalitarian ideas of the common law tradition, at least before 1789" among the "humble" the educated and the judiciary ${ }^{68}$ At the same time, as more widely accessible and presumably more procedurally dialogic American courts were assuming a more central role in both their communities and in institutional politics, courts in the United Kingdom were becoming less accessible and more central. Defending the American cause during the Declaratory Bill debate in 1766, Lord Camden received the answer, "(e)very government can arbitrarily impose laws on all its subjects". ${ }^{69}$ Property, hence liberty in contemporary understanding, was not as secure as the English (and the Americans) believed they had made it.

The task which the Scots set for themselves was to avoid the disastrous conflicts of the seventeenth century in which the constitution of the laws of the realm, and their interpretation, were posed in starkly uncompromisingly and incompatible terms. The community was to find a basis on which it could be constituted, the laws it was prepared to live by and the interpretations that would, at least, be workable compromises. James I/VI and his descendents were convinced not only that they could, like the Bourbons, establish peace among their peoples through fiat and the monopoly of policy, but that they could occupy a position beyond the boundaries of legality and, in the language of modernity, determine its limits. However, after long consideration of the

66 David Hume, The History of England from the Invasion of Julius Caesar to the Revolution in 1688 (Indianapolis: Liberty Classics, 1983) vol. 6 at 520.

67 Thomas Miller, "Where Did College English Studies Come From?" (1990) 9 Rhetorical Review 50.

68 David Lemmings, Professors of Law: Barristers and English Legal Culture in the Eighteenth Century (Oxford: Oxford University Press, 2000) at 9.

69 Ibid. at 243, 323. 
alternatives to this conviction and their viability, this position was no longer acceptable, even if it was to enjoy a sort of revival under the positivists.

There are lessons here for the present, summed up in Rahman's opinion piece in the Age. ${ }^{70}$ In a world where a US Attorney-General imagines that the freedoms of his regime are an "endowment from God" ", there is little room for rational disagreement about their content, and the resultant conflict has already proved unhappy for some, in New Orleans, in Iraq, perhaps potentially in Iran. What Hume and the Scots learned from John Locke was that the imagination that only absolute authority stood between people and chaos "is to think that Men are so foolish that they care to avoid what mischiefs may be done to them by polecats or foxes, but are content, nay to think it safety to be devoured by lions." ${ }^{\prime 72}$ Locke continued that this also was to imagine that change could only be authorized safely: that "there should be no (socially peaceable) difference in conversation (and) opposition in men's discourses". But, for Locke, Shaftesbury and their successors, to abandon toleration in this free and necessarily mannered and respectful sense,

would be to take away the greatest advantage of society, and the improvements to be made by ingenious company where the light is to be got from the arguing of men's parts.. 'Tis not the owning one's dissent from another that I speak against, but the manner of doing it. ${ }^{73}$

That "agreement of the people" in which Jefferson was to seek political community could be attained by "humanizing" the child from the earliest age. For Locke's protégé, the Third Earl of Shaftesbury, "the scene of the gentleman in polite conversation (was) a model for discursive and cultural activity and authority." ${ }^{\text {"4 }}$ Polite discussion and a patient willingness to concede an opinion after listening to criticism was to dispel both superstition and enthusiasm without recourse to the closure of authoritarian fiat, thereby expanding freedom to the benefit of all. ${ }^{75}$

It was not, however, only the gentleman, persuaded to argue gently and with his sword sheathed, in whom lay the key to peace, liberty and property. ${ }^{76}$ The Irish Presbyterian moderate, Francis Hutcheson, who spent most of his life teaching moral philosophy at the University of Glasgow, assumed that whilst not everyone could be expected to possess "virtue", it is possible "to

70 Ankon Rahman, "To end terrorism, we must first ask why it attracts people" The Age (29 September 2006).

71 Roy, Empire, supra note 2 at 143.

72 Locke, supra note 47 at para. 93.

73 John Yolton and Jean Yolton eds., John Locke: Some Thoughts Concerning Education (Oxford: Oxford University Press, 1989) at 205.

74 Lawrence Klein, Shaftesbury and the Culture of Politeness: Moral Discourse and Cultural Politics in Early Eighteenth Century England (Cambridge: Cambridge University Press, 1994) at 9.

75 Anthony Ashley Cooper, Characteristics of Men, Manners, Opinions, Times, Lawrence Klein, ed., (Cambridge: Cambridge University Press, 1999); and see Roy Porter, The Creation of the Modern World: The Untold Story of the British Enlightenment (New York: Norton and Company, 2000).

76 Porter, supra note 75; John Brewer, The Pleasures of the Imagination: English Culture in the Eighteenth Century (London: Harper Collins Publishers, 1997); GJ Barker-Benfield, The Culture of Sensibility: Sex and Society in Eighteenth Century Britain (Chicago: University of Chicago Press, 1992). 
cultivate it in ourselves; and through writing, teaching, conversation and social interaction, we can cultivate it in others." ${ }^{77}$ Virtue was, for Hutcheson, the recognition of acts of benevolence and those persons who promoted the public good. Earlier than Hume, he urged the necessity for sociability in the cultivation of virtue, and the position that "feeling rather than reason is the root of moral judgment. Proper behaviour must be grounded in the natural affections, suitably reinforced by social custom." ${ }^{\text {8 }}$ Hutcheson, Purvience observes, bases his elaborations of ethics and ethical behaviour on the necessity for constant sociability. And, for Smith, it is from society and its approbation or disapprobation of what we and others do that we construct our interior spectator who judges the propriety or impropriety of our actions even when no one else observes us, or can have knowledge of our most intimate thoughts. A man of "constancy and firmness... does not merely affect the sentiments of the impartial spectator. He really adopts them.".79

What Hutcheson does with ethics, Smith does with sociology. Hutcheson, a victim of a failed eighteenth century repetition of the Thomas Aikenhead prosecution and execution for heresy at the behest of the Kirk in 1696, ${ }^{80}$ opposed moral authoritarianism. What ethics could accomplish politically, he taught, was measure to what extent the loyalty of subjects was due to rulers. Hutcheson argued that misery, corruption, severity and force corrode national love, beneficent regard and humane sentiment and justify rebellion and independence. ${ }^{81}$

For Smith, questions of usefulness (or utility) are not abstract matters for Mankind in some general manifestation, ${ }^{82}$ but refer us to the wellknown four-stage model of social order that Smith adapted from Samuel Pufendorf. ${ }^{83}$ The model does not purport to be a description of Progress, since stages are clearly envisaged by Smith as overlapping and movement as being in no necessary direction. The point is that it is impossible to gauge the usefulness that could motivate either adherence or rejection of the propriety of authority in relation, say, to particular forms of government without knowing whether the social order was predominantly one of gatherer-hunters, shepherds, agriculturalists or of commerce. Smith is explaining bow we should understand normative instance in terms of its

77 John Bishop, "Moral Motivation and the Development of Francis Hutcheson's Philosophy" (1996) 57 Journal of the History of Ideas 277.

78 Susan Purvience, "Intersubjectivity and Social Relations in the Philosophy of Francis Hutcheson" in John Dwyer and Richard Sher, eds., Sociability and Society in Eighteenth Century Scotland (Edinburgh: Mercat Press, 1993) at 23.

79 Adam Smith, The Theory of Moral Sentiments (6 ${ }^{\text {th }}$ ed. by), D.D. Raphael and A.L. Macfie, (Indianapolis: Liberty Classics, 1982) at 110.

80 See Arthur Herman, The Scottish Enlightenment: The Scots' Invention of the Modern World (London: Harper Collins Publishers, 2001).

81 Caroline Robbins, “when is it that Colonies may turn Independent?' An Analysis of the Environment and Politics of Francis Hutcheson, 1694-1746" (1954) 3(11) The William and Mary Quarterly 151.

82 Adam Smith 3 (11) Lectures on Jurisprudence, R.L. Meek, D.D. Raphael \& P. Stein eds., (Indianapolis: Liberty Classics, 1982) at 14ff.

83 Samuel Pufendorf, On the Law of Nature and of Nations in Eight Books, in The Political Writings of Samuel Pufendorf, Craig L, Carr ed.; Michael J. Seidler trans. (New York: Oxford University Press, 1994). 
environment. His is "a sociological/institutional rather than a rationalist/ individual explanation" ${ }^{84}$ But there is a further component. Britain may be adjudged happy in the liberty and restraint that her limited form of government permits, but although the limits upon the power of the King in Parliament are not specified, "on whatever principle government may be founded... there are certain abuses which no doubt make resistance in some cases lawful". 85

\section{UNCERTAINTY}

Knowledge and a particular approach to it are shared by the Scots and their English progenitors. For Locke, the categories of science are heuristic devices for "the easier and readier improvement and communication" of ideas:

[i]n framing these ideas, the mind searches not its patterns in nature, nor refers the ideas it makes to the existence of real things; but puts things together as may best serve its own purposes, without tying itself to a precise imitation of anything that really exists. ${ }^{86}$

Hutcheson's esthetics relate ideas of beauty to their time and place. They require, not some particular objective quality in an object, but an idea in a mind that perceives. ${ }^{87}$ Hutcheson's purpose is to expose expressions of disguised prejudice, and by proposing sympathetic discussion, he aims to further sociability which, as we have seen, extends into a theory of political practice. ${ }^{88}$ In Adam Smith's posthumously-published essay on science, he insists that the laws by which scientists understand the world are not to be found in nature but in the imaginative intellectual processes through which that understanding is grasped. ${ }^{89}$ As his editors remark, had someone suggested to Smith that one day a theory more powerful than Newton's might replace Newtonian physics, he would certainly have agreed. ${ }^{90}$ For Smith, in productive, or even competitive disagreement, a focus on the process and conduct of affairs rather than on outcomes, is more likely to result in harmony.

At this point, philosophical politics can be used as a lens through which to make sense of the spirit of the first empire. There are similarities between Hume's philosophical politics and the inspiration for James Tully's

84 Christopher Berry, "Sociality and Socialization" in Alexander Broadie, ed., The Cambridge Companion to the Scottish Enlightenment (Cambridge: Cambridge University Press, 2003) 243 at 251. Also Alan Swingewood, "Origins of Sociology: The Case of the Scottish Enlightenment" (1970) 21 British Journal of Sociology 164.

85 Smith, supra note 82 at 434.

86 John Locke, An Essay Concerning Human Understanding, ed. by R.L.Meek and D.O.Raphael (Oxford: Oxford University Press, 1979) at 420, 431.

87 Francis Hutcheson, An Inquiry into the Original of our Ideas of Beauty and Virtue Bernhard Fabian, ed., (Hildesheim: Georg Olms, 1990) at 14-15.

88 See David Paxman, “Aesthetics as Epistemology, Or Knowledge Without Certainty” (1992-1993) 26 Eighteenth Century Studies 285.

89 Adam Smith, "The Principles Which Lead and Direct Philosophical Enquiries, Illustrated by the History of Astronomy" in W. Wightman and J. Bryce, eds. Adam Smith: Essays on Philosophical Subjects (Indianapolis: Liberty Classics, 1982) at 105.

90 Ibid. at 21. 
recent book..$^{11}$ In it Tully provides a haunting evocation of William Reid's sculpture, The Spirit of Haida Gwaii, which stands in the main concourse at Vancouver International Airport. The Spirit of Haida Gwaii is a black canoe containing apparently incompatible creatures: distinct yet joined, squabbling yet in dialog, diverse yet necessary to each other. It is reminiscent of Hume's rowers, finding themselves at the oars of a boat and for whom cooperation arises, ${ }^{92}$ not from a prior agreement or contract, but from a convention. There is a direction, but etymology leads us to derecho, which, like Auctoritas, etymologically augmentation, implies co-operation. For Hume, the temptation to justify resistance by reference to a breach of trust or pact between subject and ruler is, to write history backwards. ${ }^{93}$ There is never a prior contract, only a continuing dialogue:

...common sense teaches us that, as government binds us to obedience only on account of its tendency to public utility, that duty must always, in extraordinary cases, when public ruin would evidently attend obedience, yield to the primary and original obligation. Salus populi, suprema lex. The safety of the people is the supreme law. ${ }^{94}$

But how does a community even reach the point at which an 'us' might come into existence and at which this provisional obligation might apply? Why are the rowers, or Reid's creatures, in the boat to begin with? Hume has told us that government rests only upon opinion, since the governed always outnumber their governors. ${ }^{95}$ Why does a group, unless powerless before a sovereign, not descend into a constant struggle of self-interest and contestation over who is the strongest, as a Hobbesian would expect? Uncertainty provides Hume with a persuasive solution. Reason does not enable us to predict whether past observed conjunctions of events will recur into the future, ${ }^{96}$ nor whether a stationary billiard ball will necessarily ricochet when hit by one that moves. ${ }^{97}$ We cannot, once our apartment door is closed, demonstrate empirically that the stairs we ascended remain in existence. Our conviction that they do so remain is a fiction, a convention we retain and share with others in order that the world may make sense to us. The defeasibility of all convictions became increasingly central to Scottish thought, however, as part of the avoidance of dogmatism. This is consistent with Smith's remarks about scientific laws, which are not defensible by reason and may be defeasible, without being "false", nor reassuring to common

91 James Tully, Strange Multiplicity: Constitutionalism in an Age of Diversity (Cambridge: Cambridge University Press, 1995).

92 David Hume, Enquiries Concerning Human Understanding and the Principles of Morals, ed. by L.A. Selby-Bigge (Oxford: Oxford University Press, 1902) at 306.

93 David Hume, "Of the Original Contract", in E. Miller ed., Essays Moral, Political and Literary (Indianapolis: Liberty Classics, 1983).

94 Ibid. at 489.

95 Ibid. at 32.

96 David Hume, Treatise of Human Nature, ed. by L.A. Selby-Bigge (Oxford: Oxford University Press, 1978) at 173.

97 Ibid. at 655. 
sense or science. ${ }^{98}$ The thought that "Tis not contrary to reason to prefer the destruction of the whole world to the scratching of my finger" to an ethical view of the world. If scientific laws are necessary, they are social conventions. If their inaccessibility to reason as proof of their absolute truth becomes unbearable, relief is socially at hand.

[n]ature herself suffices to that purpose and cures me of this philosophical melancholy or delirium... I dine, I play a game of backgammon, I converse and am merry with my friends; and when after three or four hours' amusement I wou'd return to these speculations, they appear so cold and strained and ridiculous that I cannot find it in my heart to enter into them any farther. ${ }^{100}$

Hume cannot force us to be prudent or humane, but he can point to the human necessity for sociability. He can encourage the use of the passions to, as Arendt puts it in relation to Eichmann, "think". If we kill, torture and lie, there is no truth that, whether we call it God, science, national security, honour or country, exists to justify us. It is only our passions or emotions, for which we, as social beings are responsible. Politeness, manners, a pleasing or acceptable way of expressing the disagreement essential for accomplishing social change, reinforced by the acknowledgment that established truths were characterized by uncertainty and defeasibility, underlie the constitution upon which the normative order, including law, rests.

\section{EFFEMINISM ${ }^{101}$ AND EMPIRE}

With George III's ministries after 1762, a new authoritarianism came to be asserted. Under this new order, colonists were taught to know their place. Bentham was not the first to note this trend. However over time he supplies a language in which it can be expressed. As Gerald Postema points out,

Bentham wishes to focus attention on a feature which is not a property of any particular law, but on which obedience to any particular rests: the general habit of obedience, not to any particular law, since they may change, but to the will of a sovereign lawmaker.

Like Hart... Bentham holds that the foundations of law rest... on custom or convention, but in acceptance of certain morally neutral, formality- (or pedigree-) defined criteria of validity. ${ }^{102}$

\footnotetext{
98 Ibid. at 196-7.

99 Ibid. at 415.

100 Ibid. at 269.

101 A neologism I wish were my own, but attribution will follow and its meaning made clear.

102 Gerald Postema, Bentham and the Common Law Tradition (Oxford: Oxford University Press, 1986) at $240,262$.
} 
That Bentham's attack on the Whigs' idea of a balanced constitution and their commitment to dialogic limitations on government power was a condemnation of "womanish scolding and childish altercation"103 is not without significance, as we shall see. His definition of law is the first clear statement of the doctrine of sovereignty since the time of the Stuarts:

[a] law may be defined as an assemblage of signs declarative of a volition conceived or adopted by the sovereign in the state concerning the conduct to be observed in a certain case by a certain person, or class of persons. ${ }^{104}$

Whiggery did not vanish overnight. Indeed, it was possible, almost half a century after the publication of The Fragment, for the impeccable Whig, Lord Melbourne, to exclaim to Charles Greville that "Benthamites were all fools and Austin a damned fool". Greville later wrote that Melbourne had read all of John Austin's jurisprudence and found The Province of Jurisprudence Determined, a jurisprudential application of Benthamite principles, to be "the dullest book he had ever read." "105 Until well into the twentieth century, positivists' texts on law continued to be dull. Nevertheless, the texts proved immensely successful in constructing a view of law, state and sovereignty in England and elsewhere, in which there is a 'sheep-like' citizenry who "might well end up in the slaughterhouse."106 Part of the appeal of positivist texts on law lies in the metaphysics of order it promises to substitute for the Whig metaphysics of balance. Its quintessential trope is the Panopticon, a prison designed by Bentham to, mechanize Smith's spectator, the internalized observer who approves or disapproves of our conduct. It consists of a block of cells whose inmates can all be viewed from an inspector in a tower built so as to make him invisible to the inmates. The inspector is undeniably an in-specter, since his presence or absence is unknown. ${ }^{107}$

Benthamite sovereignty was preceded by, but reinforced with an impatience with American insistence upon what they saw as, their rights as freeborn Englishmen. This was partly imparted on them through the Scots, ${ }^{108}$ and by an increasingly "pervasive view that colonies and colonists" were strategic and commercial resources. There is a temptation to portray Bentham as a kind of intellectual George Bush (Sr. or Jr.) or John Howard: a disciplinarian centralist. The principal similarity is that the policies they recommended seem like answers to certain elite anxieties and at the same time translatable into more populist simplicities. For the British rulers there was, in the mid-18 ${ }^{\text {th }}$ century, a fear of losing British possessions, and even the British Isles themselves, to the Catholic powers, principally France. This

103 Jeremy Bentham, A Fragment on Government, ed. by J.H. Burns and H.L.A. Hart (Cambridge: Cambridge University Press, 1988) at 104.

104 Jeremy Bentham, Of Laws in General, ed. by H.L.A. Hart, (London: Athlone Press, 1970) at 1.

105 Quoted in Joseph Hamburger and Lotte Hamburger, Troubled Lives: John and Sarah Austin (Toronto: University of Toronto Press, 1985) at 224-225.

106 H.L.A. Hart, The Concept of Law (Oxford: Oxford University Press, 1961) at 114; and see Peter Fitzpatrick, The Mythology of Modern Law (London: Routledge Publishing, 1992) at c. 6.

107 Jeremy Bentham, The Panopticon Writings, ed. by Miran Bozovic (London: Verso Press, 1995).

108 P.J. Marshall, The Making and Unmaking of Empires (New Delhi: Oxford University Press, 2005). 
is scarcely surprising. There had been major risings in favour of the exiled Stuart dynasty in the uprisings of 1715 and 1745, which were encouraged by Spain and France. The Highland Scottish army reached Derby in the English midlands in 1745.

Neither the evaporation of Spanish and French support for the rebellions, nor the relative indifference of those English who might have risen to support James or the Young Pretender, James II's grandson, could have been predicted before the event. The burden of Bruce Lenman's and John Gibson's collection is that the Jacobite threat, with overseas catholic support, could not at the time have been safely perceived as a paper tiger. ${ }^{109}$ Peter Marshall writes of the 'dismay' among political leaders as tension rose in the early $1750 \mathrm{~s}$, prior to what the became the first of a half century of global war among the European powers. The comprehensive victory of Britain, could not have been anticipated with any confidence at the beginning of the period. ${ }^{110}$ Given this context, there was, in the view of these rulers no room for a loosely confederated Atlantic empire of the kind the Americans in effect favoured. The example of the Dutch Republic seemed relevant at the time. The Dutch Republic was no longer a nation but a weak disabled company of merchants, sunk into 'insignificancy' because their myopic pursuit of wealth had led them to overlook the need for centralized political authority. ${ }^{111}$

The experience of domestic disorder during the Wilkite disturbances demonstrated the need for firm centralized government in Britain. Wilkes' use of the courts to restrain the conduct of an executive that had Parliamentary supportimplied a more rigorous separation of powers than many contemporary rulers considered safe. His denial of the Commons' right to decide who sat in their house, despite the outcome of elections implied that sovereignty might originate with the people. That many of the people thought this to be the case might be deduced from their increasingly vocal criticism of the political order. In Number 42 of the North Briton, Wilkes launched an attack on the executive and was arrested and his premises raided by authority of a general warrant in which neither Wilkes nor publishers were named. The King's Bench struck down the warrant and immediately dinner parties were advertised for fortytwo guests from Philadelphia to Amsterdam, forty-two candles appearing in windows everywhere were lit, and the new industrial revolution and the illicit press allowed " 42 " to appear everywhere. The satire alarmed the Executive, perhaps unnecessarily. Such civil libertarian provocations at home, and French and Spanish threats overseas, seemed to demonstrate the need for a more centralized and unified approach to empire-building. This may have been the firm intention at the time but, as Saul David observes, it was not soon to be realized outside India. By the accession of Queen Victoria in 1837, in actuality "the empire consisted of a jumbled collection of territories acquired in bits

109 Bruce Lenman and John Gibson, eds., The Jacobite Threat: Rebellion and Conspiracy 1688-1759: England, Ireland Scotland and France (Edinburgh: Scottish Academic Press, 1990).

110 Peter Marshall, “A Nation Defined by Empire 1755-1776” in Alexander Grant and Keith Stringer eds., Uniting the Kingdom? The Making of British History (London: Routledge Publishing, 1995).

111 Peter Marshall, "The Case for Coercing America Before the Revolution” in Fred Leventhal and Roland Quinault, eds., Anglo-American Attitudes: From Revolution to Partnership (Aldershot: Ashgate Publishing, 2000) at 13 
and pieces over generations, 'an unsystematic affair, an empire in abeyance, possessing no unity of purpose or sense of whole'."'112 It may have been for this reason that the despotic regime of the Raj came to have such influence on the later development of the British Empire. Despite the fact that India was a jumble, at least it was a despotic jumble, offering the possibility of unified rule.

The authoritarianism, one of whose side-effects was the disintegration of the North Atlantic Empire, had perhaps three sources. First, Wilkes' legal and political campaigns against the government together with his subversive lampooning of Lord Bute, George III's tutor and briefly Prime Minister, implied both popular sovereignty and the need for a formal separation of powers. No administration was prepared to concede. Second, the empire had moved into a new phase. With the military victories in Bengal at Plassey and Buxar and the grant of diwani - the right to collect tax - from the Nawab of Bengal and the East India Company suddenly ruled a population vastly exceeding the remainder of the empire. ${ }^{113}$ If Edmund Burke considered them to be entitled to the benefits of the British constitution, John Company's officials found a mentor in Hobbes. The third impetus to authoritarian centralism is traced by Kathleen Wilson. ${ }^{114}$ The doctrines of politeness, manners, tolerance and acceptance of diversity and uncertainty, all of which had preserved the state since the revolution, gained a new and gendered character of effeminacy. Mastery seemed to be what was required.

\section{EFFEMINACY}

James was among the last of the English officials in India who found it possible to truly cross cultures. The new ideas that (Governor-General) Wellesley imported from England... made it increasingly difficult for individuals to make the leap from Britain to India, from Georgian to Mughal, from Christianity to Islam. India was no longer a place to embrace and be transformed by; it was instead a place to conquer and transform. ${ }^{115}$

Dalrymple's James Achilles Kirkpatrick (1764-1805), was the Company Resident in Hyderabad between 1798 and 1805. Kirkpatrick married a highranking Muslim woman, Begum Khair-un-Nissa. The marriage was the subject of an inquiry by the Governor of Bengal, Clive, grandson of the victor of Plessey. As confidante of the Nizam of Hyderabad, and of the Nizam's Prime Minister, Kirkpatrick was a successful diplomat to the court of one of India's most powerful kingdoms. The inquiry was prompted by

112 David Saul, Victoria's Wars: The Rise of Empire (London: Viking Press, 2006) at 3, in part quoting James Morris.

113 A divan, in Britain a lower middle class spare bed, was originally a rectangular stone slab from which petitions would be presented to the Emperor in Delhi, and after the fragmentation of the empire, his successor rulers in various princedoms. It signified Authority, the right to rule, but in turn, the obligation to hear the respectful expression of grievances.

114 Wilson, supra note 49.

115 William Dalrymple, White Mughals: Love and Betrayal in Eighteenth Century India (London: Harper Collins Publishers, 2002) at 454. 
several issues. One issue was his marriage to a girl (she was fourteen when he married her) who was of so high a rank. Another was his own adoption of Mughal dress - a habit well-suited to the climate and long common among Europeans, as Van Dyck's famous 1620s portrait of the first Earl of Denbigh in Indian clothes suggests. In general, Kirkpatrick's acceptance of the EuroIndian synthesis into which, as Dalrymple makes plain, intercourse in the multicultural world of India took for granted, made him an anachronism like those two ironically antagonistic figures, Warren Hastings and Edmund Burke, hence the scandal that provoked the inquiry urged on Governor Clive. ${ }^{116}$ The briskly efficient Cornwallis (Governor-General of India 1786-1793, then 1804-5) and the more Martinet-like Wellesley (1793-1804) represented a new world, one in which political subordination began to be justified in terms of the innate superiority of the subordinators. ${ }^{117}$ In the clash of civilizations and of classes, we still live with consequences of doctrines of innate superiority and inferiority.

There are a number of contexts in which to put both Kirkpatrick's behaviour and the responses to it. Jyotsna Singh, addressing a broader question remarked that "the (British) concern for good governance in India also exposed the growing anxieties about the attendant social and economic dislocations that were taking place within British society." 118 It came as a shock to an English culture whose rudimentary education system elevated the language and culture of classical Athens and Rome above all others, to learn from the work of orientalists such as linguist-lawyers HT Colebrooke and Sir William Jones that Sanskrit both preceded historically and exceeded in sophistication the languages of the classical Mediterranean that underwrote British proof of European superiority. That Sanskrit itself may have been a product of a proto-Indo-European language originating in South Asia and the root of Greek and Latin, added insult to injury and prompted ludicrous stories, for example, that Alexander the Great's Indian adventures had enabled wily Brahmins to invent a language based on Macedonian Greek and pass it off as more venerable. The evidence of an Indian past of high civilization, and of linguistic and other accomplishments could be used to measure a regression in the present requiring British dominion to reverse it to the point where Indian subjects were once again capable of governing themselves - in the future.

Jones' genuine respect for Sanskrit culture was not unrelated to the desire of colonial administrators to free themselves from a reliance on native pundits, fluent in the language and the laws written in it, in applying local law to local people. ${ }^{119}$ Ironically, since it was largely the work of Englishmen, proud of the procedures of their common law, the Orientalists' attempts at

116 For earlier examples of this adaptation, and its propriety, see Percival Spear, The Nabobs: A Study of the Social Life of the English in $18^{\text {th }}$ Century India (London: Oxford University Press, 1963) at c 2.

117 Ibid. at c 8 .

118 Jyotsna Singh, ColonialNarratives/Cultural Dialogues: "Discoveries" of India in the Language of Colonialism (New York: Routledge Publishing, 1996) at 53.

119 C. A. Bayly, Indian Society and the Making of the British Empire (Cambridge: Cambridge University Press, 1988) at 113; Bernard Cohn, Colonialism and its Forms of Knowledge: The British in India (Princeton: Princeton University Press, 1998) at c 3 [Bayly, Indian Society]. 
codification prefigure Weber's obsession with formal legal rationality ${ }^{120}$ and seem paradoxically to replace a Hindu caselaw procedure with one that replaces and rigidifies it. The inconsistencies which the Orientalists sought to remedy in their translations of the Laws of Manu are attributable, according to Brian Smith, to its context-sensitivity, not to a failure of intellectual rigour. ${ }^{121}$ The notion of dharma as encompassing appropriate behaviour, religion, right and law, was not so distant from early eighteenth century British ideas about social order.

Kirkpatrtick's adaptation to the enormous variety of Indian ways acquired a different complexion under the new dispensation that was not so much critical of Indian culture as a whole, but increasingly contemptuous. Singh suggests that for those who became increasingly authoritative, and who saw the richness of the Indian past as a measure of its current inhabitants' fall from grace, there was evidence of the need for a profound rehabilitation of Indian culture. The "public mind... of India, we found debased and contracted," the "race debased by three thousand years of despotism and priestcaft...sunk in the lowest depths of slavery and superstition." 122

During the eighteenth century there was a struggle over the notion of citizenship in Britain. The proper subject of political discourse took on a hegemonic form that stressed "rationality", "independence" and "manliness". ${ }^{123}$ The conception of the proper subject of political discourse was limited to white men with a masculine bearing. Dror Wahrman issues a cautionary reminder that such self-representations of those who positioned themselves rhetorically as opposed to both an "effeminate" aristocracy of the metropolitan court and the unruliness of the mob have a provenance extending at least to the seventeenth century, ${ }^{124}$ and he warns that some at least of the "rise of the middle class" social histories are too simplistic. Moreover, as Dror Wahrman argues, the politically powerful mid-Victorian middle class of the "middle class values of hearth and home" may largely be a projection of late nineteenth and twentieth century social analysts, writing from a patriarchal perspective. ${ }^{125}$

Wahrman may, however, push his case too far. ${ }^{126} \mathrm{He}$ does well to emphasize the profoundly misogynist turn that overtook Britain in the late eighteenth

120 Max Weber, Economy and Society, vol. 2 (Berkeley: University of California Press, 1978) at c. 8. See also Anthony Kronman, Max Weber (London: Arnold Publishers, 1983).

121 Brian Smith, "Introduction" in The Laws of Manu, Brian Smith and Wendy Doniger eds., (Harmondsworth: Penguin Publishing, 1991) at 44.

122 Thomas B. Macaulay, "Speech on the Government of India, House of Commons $10^{\text {th }}$ July 1833" in T.F. Ellis ed., The Miscellaneous Writings and Speeches of Lord Macaulay (London: Longmans Green and Co., 1889) at 563, 572 [Macaulay, Writings and Speeches].

123 See Ronald Hyam, Empire and Sexuality: The British Experience (Manchester: Manchester University Press, 1991); Andrew Parker et al eds., Nationalisms and Sexualities (New York: Routledge Publishing, 1992)

124 In relation to India, for example, see Kate Teltscher, "Maidenly and Well-Nigh Effeminate': Constructions of Hindu Masculinity and Religion in Seventeenth Century British Texts" (2000) 3 Postcolonial Studies 159.

125 Dror Wahrman, Imagining the Middle Class: The Political Representation of Class in Britain, c 1780-1840 (Cambridge: Cambridge University Press, 1995).

126 See Leonore Davidoff and Catherine Hall, Family Fortunes: Men and Women of the English Middle Class 1780-1850 (Chicago, University of Chicago Press, 1987); John Tosh, A Man's Place: Masculinity and the Middle Class Home in Victorian England (New Haven: Yale University Press, 1999). 
century, one which had consequences well beyond essentialized relations between men and women. The empire depended upon the 'public man',

$[w]$ hereas the "feminine" was relegated to the realm of pleasure, eroticism, artifice, sociability and particularity. Not only women, but a range of racial and ethnic "others", from Africans to Highland Scots, as well as the English lower classes were identified in much cultural and political discourse with the symbolic feminine, as dependent, irrational, sensual or emotional. ${ }^{127}$

With her neologism, 'effeminism', Revathi Krishnaswamy provides a useful term with which to capture a late eighteenth century erotics that involved an economy not of masculinity and femininity, but of masculinity and effeminism. ${ }^{128}$ Like the natives of torrid climes, women were taken to lack the courage, rationality and restraint from emotion of the proper white man. A letter from T.B. Macaulay on his travels in India describes an evening of "prodigious jabbering" by brown people, followed, the next morning by Macaulay's account of his rescue of his servant, who had been set upon by "rascals" who had nearly stripped him naked, in which he stated, "I supported the poor wretch in my arms for, like most of his countrymen, he is a chicken-hearted fellow and had nearly fainted away." ${ }^{129}$ Krishnaswamy quotes William Hodges' comparison of a group of Bengali men in conversation to an "assembly of females", their "delicate features adorned with jewellery, their silks, linen and muslin 'dresses'," while yet others were "wholly naked".

The letter is interesting for a number of reasons. The servant in this case was accused of a legal offence about the authenticity of which Macaulay has doubts. Here we have a kind of vigilante justice on both sides, which sits uncomfortably with Macaulay's insistence on the crucial nature for British rule of the utmost probity and adherence to law. The incident reminds us of Robert Harvey's response to the passage in the Essay on Clive in which Macaulay stresses the difference between British Company practice and the reliance it encouraged as well as the caprice of local rulers who provoked the opposite. Victorian cant, Harvey observed that: the British ruled by virtue of possessing an effective mercenary army whose power was eventually overwhelming. ${ }^{130}$ More importantly for present purposes is the importance of clothes, and the lack thereof. One of Burke's less happy moments in Reflections, ${ }^{131}$ some decades earlier, had been of a brief infatuation with the vision of Marie Antoinette, then dauphiness, as she passed him, magnificently-apparelled "glittering like the morning star," her feet seeming to Burke scarcely to touch the ground. Some years later, when she had become Queen and the Revolution was under way, a mob, notoriously bras-nus and sans-culottes, broke into her bed-chamber

127 Wilson, supra note 49 at 45.

128 Revathi Krishnaswami, Effeminism: The Economy of Colonial Desire (Ann Arbor: University of Michigan Press, 1998) at 19, $21 \mathrm{ff}$.

129 Quoted in George Otto Trevelyan, The Life and Letters of Lord Macaulay (London: Longmans Green, 1876) vol. 1at 386.

130 Robert Harvey, Clive: The Life and Death of a British Emperor (London: Hodder and Stoughton Publishers and Company, 1998) at c. 15.

131 Edmund Burke, Reflections on the Revolution in France (London: Dent Publishing, 1910), at $73 \mathrm{ff}$. 
- in itself an account, whether true or not, heavy with sexual innuendo - and chased her "nearly naked".

The beautifully and delicately dressed are 'effeminized, as are those nearly naked. Hodges' Bengali men are gendered feminine by their finery, as was Marie Antoinette. Her finery was authorized royalty, theirs a kind of transvestitism. The boatmen and the fleeing queen are similarly eroticized in their openness to public view. If we see Hodges' and Macaulay's accounts through the passages in Burke, we see that clothes represent civilization and culture. Unclothed humans are merely animals; unclothed women are secondrate humans, like unclothed Bengalis.

As the East India Company was transformed from a mercantile company trading in the area into the government of tens of millions of subjects, alliances with Indian rulers, curiosity about and respect for Indian culture and laws, and even assimilation to local custom, were transformed. If the British Empire in India had no higher purpose than to yield profits to the shareholders of the East India Company, then, as Trautmann points out, there was now a 'nobler purpose': the moral uplift of the Indians from their degraded condition. ${ }^{132}$

Robert Clive, grandfather of the governor to whom the Kirkpatrick "problem" was referred, certainly found what could be constructed as a lack of "manliness", in his encounters in India. ${ }^{133}$ What Clive thought of Indian culture and people is neither clear nor relevant, since "Clive" was in fact a crucial trope in the justification of conquest and rule in India. A historiography, of which Macaulay's formed a part, only too convenient for the historians of the second empire, represented an India descended into political incoherence with the struggles that preceded and followed the death of the last effective Mughal emperor, Aurungzeb, in 1707. In Macaulay's formulation, in the subsequent anarchic hiatus, a great civilization sank into decadence, passivity and decay. Into this field there entered the two principal European forces of South Asia: ${ }^{134}$ France and Great Britain (represented by the East India Company). They were motivated by the desire for conquest and the destruction of British power. In this narrative, the embodiment of French guile and their preparedness to ally with deceitful native rulers, was the "small, vigorous and disdainful" Francois Dupleix. ${ }^{135}$

Modern narratives note the formation of vigorous sub-states formed from the provincial organization through which the Mughals had ruled an extremely complex empire and the way in which they and the close connections between Indian creditors, Indian rulers and British merchants facilitated the growth of British domination. ${ }^{136}$ As this increased through a form of racket in which Company troops, paid for from local revenues, would "protect" the local ruler, the vigour of the sub-states abated. By the mid-Victorian threshold of the 1857 insurrection, this system, so C.A.Bayly argues, had

132 Ibid.

133 Harvey, supra note 130.

134 Thomas B. Macaulay, Essay on Lord Clive (London: Dent Publishing, 1920) at 34

135 Ibid.

136 Richard Barnett, North India between Empires: Awadh, the Mughals and the British, 1720-1801 (Berkeley: University of California Press, 1980). Bayly, supra note 119 at c. 1. 
substituted for a nascent form of capitalism, and simply imposed another level of rentier, the Company, draining the system of wealth and reducing the capacity of native Indians to buy British goods.

When Bayly refers to the sovereignty of the Mughal emperor, he has in mind something different from the conception that Bentham took from Hobbes: "overlapping rights and obligations" and the Moghul's role as final arbiter of the authority of the prophet." ${ }^{\prime 37}$ Bayly remarks that the early British tactic of acknowledging this form of authority facilitated acceptance of the beginning of their rule. ${ }^{138}$ As P.T.Marshall puts it, "no observer in 1765 could have envisaged ... British supremacy over the whole of India. The Company had by then become "Indian rulers... of some consequence" according to Indian political principles, and were dependent on traditional practices of revenue-raising in the same nominally - delegated way as the former ruler of Bengal. Marshall adds that many Indians hoped that "the British might become assimilated into an (Indian) aristocracy committed to Mughal values." "The grant of the diwani to the Company by the Mughal Shah Alam was on condition that Islam and the "law of the Empire" should be respected. "Warren Hastings, the ruler of British India from 1772 to $1785 \ldots$ felt that the British administration should be conducted' agreeably to the old constitution of the Empire."."140

\section{THE UTILITARIANS, MANLINESS AND LORD CLIVE}

The irrebuttable pretence during Robert Clive's time-that Company sovereignty could be concealed behind the Mughal's apparent delegation of authority-was followed by Cornwallis's restructuring, one derived from eighteenth century Whig principles, namely,

[t]hat political power is essentially corrupting and inevitably abused; that power, to be exercised with safety, must be reduced to a minimum and even then kept divided and counterbalanced. ${ }^{141}$

This implied the separation of powers and the scrutiny of executive action by an independent judiciary. But Cornwallis's Whig principles were essentially English, and implied in their turn the Anglicization of the Bengaliadministration and the exclusion of Indians. This exclusion, Cornwallis continued, was the belief of the inherent superiority of the "Anglo-Saxon race" when it came to conceptions of law and government, and an insistence that "we cannot avoid recognizing in the people of Hindostan, a race of men lamentable degenerate and base... retaining but a feeble sense of moral obligation". The "corruption of manners", the natives" "vices" and the "misery" that this state of affairs

137 Bayly, ibid. at 13.

138 Ibid at 16.

139 P.J. Marshall, “The British in Asia: Trade to Dominion, 1700-1765”, in P.J. Marshall ed., The Oxford History of the British Empire (Oxford: Oxford University Press, 1998) vol.2 at 505.

140 Rajat Kanta Ray, "Indian Society and British Supremacy" in P.J. Marshall ed., The Oxford History of the British Empire (Oxford: Oxford University Press, 1998) vol.2 at 510.

141 As quoted in, Eric Stokes, The English Utilitarians and India (Oxford: Oxford University Press, $1959)$ at 5. 
entailed could not but require guidance by others more enlightened. Good government in such circumstances was much better than free government and very much better than consulting the natives or giving credit to their customs and expectations.

As "notions of positive law, judicial process..." were introduced, "for Wellesley and his supporters it was essential that the company and particularly the Governor General should stand forth as sovereigns" ${ }^{142}$ in the Hobbesian tradition in dealing with Indian powers and their own subjects

[t]he Governor-general 'should have the power of summoning a privy council and should act in it as the King or the LordLieutenant of Ireland'. The ancient corporate nature of the Company councils with their near-equality between members should be dispensed with.for these had the character of an aristocratic republic rather than a monarchy.,143

To Wellesley, "it was obviously necessary that the Governor General in Council should exercise the entire legislative authority (excluding) our native subjects from all participation in the legislative authority," ${ }^{144}$ the safeguard being an independent judiciary. The "natives" themselves were by no means convinced of the satisfactory nature of "despotism... without any regard for the shari'ah and for custom," ${ }^{145}$ in increasingly broad areas of Company conquests.

Whilst the Utilitarians were encountering resistance from Whigs and WhigLiberals, and would soon meet popular opposition in the United Kingdom, the most favourable condition of existence for their social engineering projects was available in India: the doctrine of law as nothing more than the sovereign will "the (European) eighteenth century despot in altered guise." 146 The Charter Act of 1833 reinvigorated the Supreme Council and authorized the setting up of a Law Commission to inquire "into the nature and operation of all laws whether civil or criminal, written or customary." ${ }^{147}$ It seemed to Macaulay that "India stands in need of a code (i.e. a code of laws) more than any country in the world." It was better that it was drafted by one man or a few expert men than by a committee or an assembly, as would inevitably be the case in Britain. "It is a work which especially belongs to government like that of India, to an enlightened and paternal despotism." 148

The Indian Civil Service College at Haileybury, which had political economist, Thomas Malthus, on its faculty, already taught Benthamite principles, although their influence on students may have in the early days

142 As quoted in ibid.

143 As quoted in Bayly, supra note 119 at 82

144 As quoted in Bayly, ibid.

145 Ibid. at 526.

146 Stokes, supra note 141 at 173. Naturally, as Stokes remarks (at 177), "Bentham found himself more at home with the enlightened despots than turbulent assemblies, for is not the legislator in some sense necessarily single and despotic?"

147 John Clive, Macaulay: The Shaping of the Historian (Cambridge MA: Harvard University Press, 1987) at 427.

148 Ibid. at 570. 
been limited by the low intellectual standards of the curriculum and the poor motivation of the students. On its publication in 1817, James Mill's History of British India was one of the texts used by the students, informing them that Indian culture "represent(ed) the rudest and weakest state of the human mind." 149 That the author had not been to India and knew little of the culture seemed to him to lend his assessment the more objective. ${ }^{150}$ Mill was both a friend and a disciple of Bentham and centrally placed in the Company's bureaucracy in Leadenhall Street. At a farewell dinner for Bentinck prior to his departure to become Governor-General of British India in 1827 it was, according to Stokes, to James Mill to whom Bentinck addressed his famous remark, "I am going to British India, but I shall not be Governor-General. It is you that will be Governor-General."'151

At about the same time that indigenous Australians were politically invisible to the British invaders, and their land thus terra nullius, the British Empire more broadly "in the nineteenth century was premised on the presumed nonexistence of extant 'native' political societies." 152 It was convenient that Mill's History "not only designates India's inert insufficiency ... as part of the study of Britain, (it) also designates Britain as the compensator for this insufficiency." As Bentham was to put it a decade later:

...you may find it difficult to give them (i.e. the inhabitants of India) to themselves. If it is determined that they must have masters you will then look out for the least bad ones and... I question whether you would find any less bad than our English company. ${ }^{153}$

Later writers claimed for Britain and the Empire, the invention of India, according to Mehta. Before colonization there was no national unity, no "India.. according to European ideas." "154 Hindu and Muslim laws were a "disorderly compilation of loose, vague, stupid or unintelligible" propositions." ${ }^{155}$ The void could therefore be filled with the great codes of law, prisons modeled on the Panopticon, and centralized agencies for the whole country, which were unencumbered by boards of governance, characterized by "uniformity of management and unity of authority." ${ }^{\prime 56}$ Colonizers would administer everything from telegraphs to railways to grand schemes of irrigation - which Rhada d'Souza tells us, did not work well, eliding, local knowledges as they did. ${ }^{157}$

As Majeed makes clear, Mill insists that only a society in which the criterion

149 Cited in Uday Singh Mehta, Liberalism and Empire: A Study in Nineteenth Century British Liberal Thought (Chicago: University of Chicago Press, 1999) at 90.

150 Stokes, supra note 141 at 53.

151 Ibid. at 51 .

152 Mehta, supra note 149 at 68.

153 Quoted in Javed Majeed, Ungoverned Imaginings: James Mill's 'The History of British India' and Orientalism (Oxford: Oxford University Press, 1992) at 125.

154 Mehta, supra note 149 at 149, citing the English historian, Seeley and John Strachey, a Victorian colonial administrator.

155 Quoted in Majeed, supra note 153 at 132.

156 Stokes, supra note 141 at 247,251

157 Rhada d'Souza, "International Law - Recolonizing the Third World? Law and Conflicts over Water in the Krishna River Basin" in Diane Kirkby and Catherine Coleborne eds., Law, History, Colonialism: The Reach of Empire (Manchester: Manchester University Press, 1991) at c. 15. 
for every action was its utility could count itself as fully civilized. Further, only a universal legislator, a sovereign able to make comprehensive and universally applicable and comprehensible laws compatible with this criterion, could deliver this civilization. In India, only the Company, through a progressive Governor General and a civil service drawn largely from the "middling ranks" of British society, would accomplish this. Equally clear, according to Majeed, is that Mill's History doubled as a criticism of Britain itself. Whilst the later Bentham and James Mill notoriously advocated democratic government for Britain, ${ }^{158}$ they did so because they conflated politics and the market place and understood voting as the demand side of what later economics would describe as the demand-supply equation. They were convinced that in practice, the middling ranks had the "requisite intellectual, moral and economic qualities which would enable them to set the tone for society as a whole." ${ }^{159}$ Democracy was, for both writers, merely a mechanism for the achievement of utility. At root, Stokes has argued, utilitarianism was an authoritarian doctrine and the enfranchised working man was to respect its principles under the tutelage of those with more capacity and vision than himself.

But what if he did not? We return once again to the basis of order in the constitution: not of the state, but of the subject. Thomas Babbington Macaulay was the rhetorical master player in the success of the Reform Act of 1832, which rationalized Parliamentary constituencies to reflect the changing demographics of Britain and modestly extended the franchise. He recognized the importance of subject-constitution and as Legal Member of the Indian Supreme Council from 1835 until 1838, he began the utilitarian program of codification in India with his draft Criminal Code. But while he could see merit in many utilitarian proposals, he was not a utilitarian ideologue. The differences between, say, Bentham, James and John Stuart Mill and James Fitzjames Stephen suggest that the closer one looks, the less one finds a unified outlook among those espousing some utilitarian principles. Whilst celebrating Bentham's jurisprudence, Macaulay opposed any significant extension of the right to vote in Britain, at least in mid-century. ${ }^{160}$ His reasons connect interestingly with what was earlier called, after Krishnaswami, effeminism.

First, though, it is helpful to notice the somewhat later conclusions of utilitarian and Hobbesian James Fitzjames Stephen, a member of the Supreme Council in India for two and a half years in the 1870s, and a judge in England from 1879 until 1891. In his discussion of the middle term in Liberty, Equality, Fraternity, Stephen responds to the views of John Stuart Mill on the place of women in society. ${ }^{161}$ In Stephens' view, men are not only physically stronger,

158 James Mill, "Essay on Government" in Jack Lively and John Rees, eds., Utilitarian Logic and Politics: James Mill's 'Essay on Government', Macaulay's 'Critique' and the Ensuing Debate (Oxford: Oxford University Press, 1978).

159 Majeed, supra note 153 at 174.

160 Jack Lively and John Rees, "Introduction” in Jack Lively and John Rees, eds., Utilitarian Logic and Politics: at 49-50 and T.B. Macaulay, "Mill's Essay on Government" in James Mill, 'Essay on Government: Macaulay's 'Critique' and the Ensuing Debate (Oxford: Oxford University Press, 1978).

161 James Fitzjames Stephen, Liberty, Equality, Fraternity (1873), (Cambridge: Cambridge University Press, 1967) at c. 5. 
but stronger intellectually, with additionally "greater vigour of character."162 "Strength, in all its forms, is life and manhood. To be less strong is to be less of a man, whatever else you may be." 163 This opened the way for the intersection of gender, class and race ${ }^{164}$ and, indeed 'he thought that in India he had found a combination of effective and benevolent government that was wanting in his own country." 165 Stephen realized that democracy in Britain was a certainty, the only uncertainty being the form it would take. Perhaps the government of the weaker by the inherently stronger, in the colonies and in the home, provided a model that would mitigate the threat of rule by majority, or at worst, provide a consolation.

Inherent superiority and inferiority implied for Stephen, a situation where a division of labour was justified. Since Stephen assumed women generally to be incapable of achieving an education that would provide them with an earning capacity, and instead assumed women to be the primary childcarer, and to lose their physical attractiveness at a younger age than a man, it followed that, equal treatment would amount to oppression. Women required protection, not independence. Moreover, because this dependency seemed to imply marriage, marriage should remain indissoluble; the relation needed to be inescapable, since, without a husband to protect her, she would be helpless and, perhaps a prey to debasement and vice. In marriage, by analogy with a ship, or a factory, there must be a master and an obedient recipient of commands if things are to proceed in an orderly fashion, even where the recipient is more skilled than the commander. Thus, the wife's promise to obey her husband must be taken absolutely seriously.

There are two matters worthy of note. First, there are in this model, not only men who are stronger and women who are weaker, but also degrees of manliness, and in both cases, whilst the weaker are entitled to the protection and kindness of the stronger, they must also defer to the stronger. Second, even if we were to ignore the point about degrees of manliness, the existence of strong women who engaged in heavy manual labour was widely acknowledged, not only by the surprising number of men in the early days of photography, who were obsessed by them, ${ }^{166}$ but evident to any dedicated London pedestrian, of whom Stephen was one. There was some concern, among the male working and middle classes, about the abilities of women. The male working class supported labour reforms that excluded women from mines and limited their hours of work in factories. ${ }^{167}$ Further, the mathematization of economics excluded women such as Harriet Martineau and there was a secret admission that women were not unequal to men. ${ }^{168}$ The

162 Ibid. at 194.

163 Ibid. at 199.

164 See Anne McClintock, Imperial Leather: Race, Gender and Sexuality in the Imperial Contest (New York: Routledge Publishing, 1995)

165 James Colaiaco, James Fitrjames Stephen and the Crisis of Victorian Thought (London: Macmillan Publishing, 1983) at 153.

166 Derek Hudson, Munby: Man of Two Worlds (London: John Murray Publishing, 1972); McClintock, supra note 158.

167 See Mary Lyndon Shanley, Feminism, Marriage and the Law in Victorian England (Princeton: Princeton University Press, 1989) at 93-102.

168 See Dierdre David, Intellectual Women and Victorian Patriarchy: Harriet Marineau, Elizabeth Barrett 
construction articulated by Stephen is thus not a piece of essentialism, but the manufacture of the subject-positions that were consistent with his sovereigncommand model of law and government.

It is possible now to return to Macaulay, "Clive" and manliness. Clive, the man and the eventual General and Governor of Bengal, began his Indian career as a writer (or clerk) for the East India Company in 1743, in time to witness the ignominious defeat of the British by the French, and the French occupation of the British East India Company's Presidency of Madras. Primarily commercially-oriented in the mid-eighteenth century, the Company was according to conventional accounts, militarily amateurish and inept, especially in comparison with its French equivalent, and its troops were poorly trained and badly equipped. Clive joined the Company's army in 1751 to fight the French and their allies, and by virtue of two spectacular successes, the first at Arcot in 1756, the second at Plessey in 1757 became the catalyst for a change in the Company's direction from mercantile company to the semi-private arm of British imperial power in India. He served three terms in India, the third of which was quite short, and proved to be an able administrator as well as a skilled and daring military tactician. "Till (Clive) appeared, his countrymen were despised as mere pedlars, while the French were revered as people formed for victory and command." ${ }^{169}$ Macaulay's Clive performs more subtle functions than those of the "soldier heroes" of Graham Dawson's recent text where,

[t]he modern tradition of British adventure has furnished idealized, wish-fulfilling forms of masculinity to counter anxieties generated in a social world that is deeply divided along the fracture lines of ethnicity and nation, gender and class. The soldier heroes (are) ideally powerful and free from contradictions and undermining effects of anxiety. They offer the psychic reassurance of triumph over the sources of threat, promising the defeat of enemies and the recovery of that which is valued and feared lost. ${ }^{170}$

By the time of the Essay, the freebooting days of British India, in which "Bengal was a place to which Englishmen were sent only to get rich, by any means, in the shortest possible time," were over ${ }^{171}$. Clive, the trope, certainly figures in Macaulay's Essay as a paean to the manliness critical if the empire and the sovereignty of law are to be maintained, but his Essay is both cautionary and celebratory in its didacticism. The moral successes and failings of the legendary character delineate the boundaries of order of the Essay and the impulse behind it explains some of the inconsistencies, hypocrisies noted by Harvey. ${ }^{172}$ Macaulay begins what is nominally a review

Browning, George Eliot (Ithaca: Cornell University Press, 1987). George Eliot had been editor of the Westminster Review, a vehicle for ideas to which Stephen would have been in sympathy.

169 Richard Wilson, ed., Macaulay's Essay on Robert Clive (London: Dent Publishing, 1920) at 149.

170 William Dawson, Soldier Heroes: British Adventure, Empire and the Imagining of Masculinities (London: Routledge Publishing, 1994) at 282.

171 Wilson, supra note 169.

172 Harvey, supra note 130. 
of a biography of Clive written by John Malcolm. He writes that "every schoolboy" knows about the Spanish conquest of South America: a conquest over a meagre population of "savages without letters", armed, in his account of them, with nothing more sophisticated than spears, bows and arrows. However, the far greater accomplishment of the "Englishmen" who prevailed over a civilization with rich bankers and enormous armies with skilled cavalry, artillery, modern muskets and armoured elephants, has been made to seem "insipid... positively distasteful" $"$ " However, this Indian civilization at its height was "far worse governed than the worst governed parts of Europe now are" $" 174$ and in its disintegration from the Moghul Empire to independent provinces evidences, "nominal sovereigns sunk in indolence and debauchery, saunter(ing) in secluded palaces, chewing bhang, fondling concubines and listening to buffoons." 175

Clive brought qualities to India not hitherto discerned in his manly but willful youth in England: "judgment, sagacity, deference to legitimate authority"176, "firmness, vigilance and ability"177, thereby winning loyalty from the British under his command and adoration from the sepoys at Arcot and elsewhere ${ }^{178}$. Bengal was won, in the terms of the Essay, not in an aggressive war, but as a response to the capricious and sadistic Nawab, Suraj-ad Daula, (in Macaulay's 'Surajah Dowlah'), whose capture of Calcutta had resulted in the deaths of British captives in the infamous "Black Hole of Calcutta". Clive's was a war against atrocity and oppression in a province where, writes Macaulay, citing a "Castilian... proverb... (about) Valencia... the earth is water and the men women"179, an "effeminate population"180 whose ruler "wanted spirit to adhere even during one day to a manly resolution" 181.

The cautionary element relates to Clive's strategy preceding Plassey. Dealing with duplicitous orientals, he seems, according to Macaulay, to have felt it necessary to abandon the upright truthfulness with which Europeans conduct both negotiations and warfare. If Nawab Suraj-ad-Daulah's wavering ally, Omichand, would not side with Clive, Clive believed his cause was lost because the Nawab's army was much larger than his own. But Clive also needed the allegiance of another, Mir Jaffir, deemed in the long run more important than the "artful Bengalee" Omichand. So two documents were prepared, one of which rewarded Omichand if he allied with Clive, and was shown only to him, and the second, the one Clive intended to rely upon, omitted any mention of Omichand. For the deception to succeed, both documents required the signature of the officer in command of naval operations, Admiral Watson. Watson, according to Macaulay, would not sign the false document, "but Clive was not a man to do anything by halves. We almost blush to write it. He forged

173 Wilson, supra note 169 at Essay 16.

174 Ibid. at 29.

175 Harvey, supra note 130 at 32; Macaulay, supra note 122 at 562.

176 Wilson, supra note 169 at 28.

177 Ibid. at 45.

178 Ibid. at 46.

179 Ibid. at 63 .

180 Ibid. at 81 .

181 Ibid. at 83 . 
Admiral Watson's name." ${ }^{182}$ When the deception was subsequently revealed to Omichand "the unhappy man sank gradually into idiocy." 183 Harvey makes the reasonable point, quoting a number of British and Indian historians of the period, that deception has always been a routine ingredient in the conduct of warfare and if, it results in the saving of many lives, as he considers it to be the case here, it is more than justified. ${ }^{184}$ Indeed, much of allied security during World War II was owed to the capture by the Royal Navy of a U-Boat carrying a German military code machine. Alan Turing's brilliant work at Bletchley, Oxfordshire, drastically reduced mercantile losses by intercepting U-Boat communications. Was this dishonourable? We would, I think, now say that it was not.

But Macaulay had a different goal, one that has some support from a contemporary:

...the natives must either be kept down by a sense of our power, or they must willingly submit from a conviction that we are more wise, more just, more humane and more anxious to improve their condition than any other ruler they could have. ${ }^{185}$

In Macaulay's view, Clive's conduct was misconceived not only because it fell short of proper standards of manly political integrity as such. It was a miscalculation because the nature of British rule in India at which Clive himself aimed depended on the perception of British probity. Once this was established, the loyalty of the sepoy army could be relied upon, and credit from Indian bankers would be available at rates lower than those loans made to princes whose unreliability necessitated higher interest. Clive, in other words, soon and well and truly redeemed himself: "[h]is name stands high on the roll of conquerors. But it is found in a better list, in a list of those who have done and suffered much for the happiness of mankind." 186 Like John Churchill, later Duke of Marlborough, who deceived his king, James II by defecting to William and Mary in 1688, thus preserving English Protestantism, property, order and liberty, ${ }^{187}$ so too Clive's victories and reforms are represented as providing a foundation for an end to corruption and exploitation. Further reform, by Clive, culminated in the legal codes that guaranteed the rule of law and underwrote the great administrative structures of social engineering.

\section{EDUCATION, ESTHETIC POLITICS}

There are indeed, modes of teaching which are producing youths of ..different stamp.. the nurselings of improved pedagogy are taught to decide; to suspect all but their own and their lecturer's

182 Ibid. at 78 .

183 Ibid. at 85 .

184 Harvey, supra note 130 at c. 15.

185 Quoted in Gauri Viswanathan, "Currying Favor: The Politics of British Educational Policy in India, 1813-1854" in Anne McClintock, Amir Mufti and Ella Sholat, eds., Dangerous Liaisons: Gender, Nation and Postcolonial Perspective (Minneapolis: University of Minnesota Press, 1997) at 113.

186 Ibid. at 152.

187 Thomas B. Macaulay, History of England, vol. 2 at $279 \mathrm{ff}$. 
wisdom and to hold nothing sacred from their contempt but their own contemptible arrogance: boy-graduates in all the technicals, and in all the dirty passions and impudence of anonymous criticism. ${ }^{188}$

Under the influence of his brother-in-law to be, Charles Trevelyan, Macaulay had a second major concern during his time in India, notably education. As a colonial administrator, he was proposing to impose a code of laws, drawn from the perspective of the colonial power on a colony. As a good positivist, he saw normative apparatuses such as statutes, judicial decisions and codes, from three perspectives.

The first and most elementary question positivists ask when confronted with what is asserted to be a law is the following: 'did it emanate from or was it properly issued on behalf of, the legitimate source of law-making power within the jurisdiction?' A sub-question that has troubled positivists is whether that source acted with legal propriety, and who is in a position to make a decision about that. Sovereignty is frequently a vexed issue, one that has taken the United States in one direction and, until the appearance of the European Union, the United Kingdom in another, after the mid-eighteenth century. The "war on terror", which seems immeasurably to have strengthened executive power in the US, de facto may affect the separation of powers in the United States in the twenty-first century. ${ }^{189}$

A second question recognized by legal positivists is whether particular laws are good or bad in a moral sense. For early positivists, dabbling with Hobbesian notions of sovereignty was not the dangerous business identified by Hobbes' early critics. Although they distinguished law from morality, moral evaluation seemed as scientifically accessible to them as the assessment of whether a rule was or was not a valid law. Bentham's "felicific calculus" concerning the greatest good was a beguilingly accurate curb on a sovereignty that threatened to run amok, if, and this is a qualification that connects with the third question, that where there is freedom of expression and an informed citizenry. The early positivists were insistent that citizens could be both informed about the general good and positioned so as to compare their situation with that good in order to take responsible steps to remedy anything unsatisfactory. This takes us back to the works of Locke, Shaftesbury and others on education. But they were concerned with an elite whilst, when the men of the nineteenth century surveyed the horizon, they noticed the challenge - or the threat of democracy.

A third question recognized by legal positivist concerns democracy. For

188 Samuel Taylor Coleridge, Biographia Litereraria, ed. by Nigel Leaske (London: Everyman Paperback Classics, 1997) at 8 .

189 Reagan US Supreme Court appointee, Sandra Day O’Connor warned in her retirement speech that recent attacks on the US judiciary were "putting the democratic fabric in jeopardy" and were the first steps down the treacherous path to dictatorship; Jonathan Raban, "Dictatorship is the Danger" The Guardian (12 March 2006). Although see the US Supreme Court's ruling that the detention of untried people at the US base in Cuba on the ground that they may have been terrorists violates the US Constitution. Insight Section The Age, (1 July 2006), 5. Predictably, this will lead to further litigation and longer periods of detention, especially for "citizens" of countries where a passport is merely a form of "ticket of leave", merely a revocable grant of freedom: see Antonia Quadara, "David Hicks in/as the Event of Terror" (2006) 24 Australian Feminist Law Journal 141. 
Bentham and James Mill, democracy was a challenge. Freedom of expression and representative government were for them inseparable and, John Stuart Mill tells us,

[s] o complete was my father's (i.e. James Mill's) reliance on the influence of reason over the minds of mankind, whenever it is allowed to reach them, that he felt as if all would be gained if the whole population were taught to read, if all sorts of opinions were allowed to be addressed to them... if by means of the suffrage they could nominate a legislature to give effect to the opinions they adopted. ${ }^{190}$

James Mill and other older utilitarians believed in the "unlimited possibility of improving the moral and intellectual condition of mankind by education". ${ }^{191}$ So convinced is J.S. Mill by the social ordering capacity of a rationality emerging from instruction that a major criticism which he makes of Disraeli's later suffrage reforms, is that plural voting was tied by Disraeli to property rather than to education. ${ }^{192}$ But neither of the Mills nor any of their followers were unaware of the normative dimension of education. Education as enlightenment takes a pedagogical course long foreshadowed by Locke and his Northern European inspirations as both enablement, but also as the name of its components indicate, as discipline. If J.S. Mill needed reminding of this, Fred Wilson writes, he had only to recollect Coleridge. ${ }^{193}$ In the course of describing his collaboration with Harriet Taylor, Mill charts his (and their) course beyond mere democracy to socialism, but notes his reservations about unqualified extensions to the franchise:

[w]e were now much less democrats than I had been, because as long as education continues to be so wretchedly imperfect, we dreaded the ignorance and especially the selfishness and brutality of the mass. ${ }^{194}$

Three decades before, in 1840, Mill had explained the Coleridgean reaction to the philosophes' belief that the fabric of the ancient regime was so rotten that there was no remedy but to tear it all down and begin again. Mill explained that order, citizenship and the ability and willingness to subordinate one's wishes either to a negotiated conception of the common good or the characteristics upon which law and ethics depend, is the product of lifelong education. Education, in short, was a "restraining discipline" 195 produced by and helping to maintain an on-going social enterprise poised, if it worked properly, between the interests of permanence and progression.

190 John Stuart Mill, Autobiography ed. by John Robson (Harmondsworth: Penguin Books, 1989) at 94.

191 Ibid. at 95.

192 Ibid. at 227.

193 Fred Wilson, "Mill on Psychology and the Moral Sciences" in John Skorupsky, ed., The Cambridge Companion to Mill (Cambridge: Cambridge University Press, 1998) at 232.

194 Mill, supra note 190 at 175.

195 John Stuart Mill, "Coleridge" in F.R. Leavis, ed., Mill on Bentham and Coleridge (London: Chatto and Windus Press, 1950). 
In light of J.S. Mill's generous treatment of Coleridge's non-economic ideas, it may help an understanding of Macaulay's imperialist vision of education if we first turn to Coleridge's model of a state and its proper ends. Although apparently inimical to the liberal conviction that, after furnishing protection to the subject, the task of the state was to leave as much scope as possible to pursue ends chosen by him or latterly herself, the Coleridgean scheme permeated liberal politics through Matthew Arnold in the mid-Victorian era, to Leavis and the English grammar school of the mid-twentieth century. In this sense, we can see a politics of social order, of imagination in Benedict Anderson's sense, and of an order resting, as Hume would have it, on the belief of the governed. Having secured the safety of the person and the property of the subject, there remains, according to Coleridge, the "positive ends" of the state, first, to make the means of subsistence more easy to each individual; second, to secure to each of its members the HOPE of bettering his own condition or that of his children and third, the Development of those faculties which are essential to his humanity, i.e. to his rational and moral being. ${ }^{196}$

As the spring is essential to the working of a clockwork motor, so the state is essential to the fulfilment of the duties and dignities of the citizen. Linking, implicitly, his notion of the constitution to that of his eighteenth century predecessors, Coleridge entitles his last major work, The Idea of the Constitution: On the Constitution of the Church and the State, According to the Idea of Each. ${ }^{197}$ An idea is, for Coleridge, something which "could not exist in its pure rational state in the forms of men, but it could be regulative of existing arrangements which may or may not conform with it;" 198 or, as he put it elsewhere, something "known to be unapproachable as to realization, but a polar star, guiding a man's mind by approximation." ${ }^{199}$ In its narrow function, the constitution is concerned with the state, and describes the organization of government and the coordination of the interests of subjects. In England, the two forces of permanence are: first, the landed interest, represented in the House of Lords, and second, that of progression, the impulse to change associated with commerce and the professions, represented in the House of Commons. In the Lay Sermons, he made it clear that underlying and qualifying the law of property in both cases was the moral notion of a trust which the property owner should learn to recognize.

In Morrow's summary of the development of Coleridge's thought, whilst the constitution in its narrow sense could account for the state, the nation required for its constitution something more closely associated with cultivation and civilization. Coleridge was not the nostalgic worshipper of an imagined rustic past that Macaulay famously lampooned in his review of the Colloquies of Robert Southey, Coleridge's friend and one-time collaborator, "in (whose) mind... reason has no place at all." ${ }^{200}$ By the early nineteenth

196 Samuel Taylor Coleridge, “A Lay Sermon”, in John Morrow, ed., Coleridge's Writings vol 1 On Politics and Society (London: Macmillan Publishers, 1990) at 142.

197 Ibid. at c. 5.

198 Peter Kitson, "Political Thinker" in Lucy Newlyn, ed., The Cambridge Companion to Coleridge (Cambridge: Cambridge University Press, 2002) at 167.

199 Quoted in John Morrow, Coleridge's Political Thought: Property, Morality and the Limits of Traditional Discourse (London: Macmillan Publishers, 1990) at 189, n 22.

200 Thomas B. Macaulay, "Southey's Colloquies" in J. Grieve, ed., Thomas Babbington Macaulay: Critical 
century, Coleridge was in sympathy with the accomplishments of commerce, science and their application to industry. He was convinced that landed wealth had in the past, and could in the future, be made aware of its social obligations. The "commercial spirit" possessed few checks to its tendency to undermine cultivated civilization. The man, for Coleridge, preceded the citizen. The state, in the expanded sense of the nation, secures property, allies itself with "trade, commerce, free industry and the arts", but "draw(s) up into the higher ranks whatever is worthiest from below and thus maintains the principle of Hope in the humblest families." 201

Its capacity to do this rests upon the idea of a particular institution, a national church freed from narrow "priestcraft", independent of the Parliamentary classes in its property and subsistence and thus able to mediate, through its "clerisy" among the different sources of wealth and between rich and poor. Among its objects:

first, the maintenance of the Universities and the great liberal schools

second, the maintenance of a pastor and schoolmaster in every parish

third, the raising and repair of the churches, schools etc, and fourth, to the maintenance of the proper, that is infirm, poor, whether from age or sickness: one of the original purposes of the national reserve being the alleviation of those evils which, in the best forms of worthy states must arise and must have been foreseen as arising from the institution of individual property and primogeniture. ${ }^{202}$

Such a body enables the humblest human to distinguish her/himself and peers from the beasts and forms the basis of a "sound constitution of the Body Politic ${ }^{203}$

When we recall the longstanding commitment of the Presbyterian Church in Scotland to issues of welfare and education and the literati mission to assist, not only in the advancement of learning but also in the creation of an English subject dedicated to the stability and commercial prosperity, Coleridge's program is not conceptually odd. It is simply more comprehensive in its ambition to maintain a complex status quo by, for example, recruiting the more ambitious and able of the "humble" into the "higher ranks". Since Coleridge's Church and State ${ }^{204}$ as well as the earlier of his writings upon which some of the ideas are canvassed temporally preceded the developments in Indian education popularly associated with Macaulay, as with the earlier work of the utilitarians, no simple connection can be made between regulatory

and Historical Essays,vol. 2 (London: Dent, 1907) at 188.

201 Coleridge, supra note 188 at 190.

202 Morrow, supra note 199 at 188.

203 Morrow, supra note 199 at 198.

204 Samuel Taylor Coleridge, On the Constitution of the Church and State, ed. by John Colmer in Coleridge, Collected Works of Samuel Taylor Coleridge, 16 vols. (Princeton: Princeton University Press, 1976), vol.10. 
social experiments in India and those in the metropole. However, as with the utilitarians, it is the concept of sovereignty, justified by the improvable inferiority of the natives that provides the vehicle in which social engineering practices can ride from a perceived periphery to a reconceived centre.

If Cornwallis and Wellesley could, at the turn of the century, draw up schemes for controlling natives on the grounds of their sovereign authority to do so, then it became natural to centralize the administrative control of the English poor three decades later. Cornwallis's Anglicization of administration in British India has a direct parallel in the transfer of Poor Law administration from the parish vestry, in which the poor themselves were often involved in one way or another ${ }^{205}$ to the "Three Kings of Somerset House" by the Poor Law Amendment Act of 1834. It was indeed, according to a recent study, ${ }^{206}$ the political economy of Thomas Malthus, lecturer to (British) Indian Civil Service students at Haileybury, which informed the new doctrines that justified workhouses and "less eligibility". These doctrines forced the poor, who had no means of earning, to separate from spouses and children, all of whom were to be subject to living conditions deliberately made harsher than those outside.

Macaulay's purpose in rejecting the legacy of Indian culture and substituting that of the British was clear from his speech to the Commons on the Charter Act in 1833, and is worth quoting at length:

[t]o have found a great people sunk in the lowest depths of slavery and superstition, to have so ruled them as to have made them desirous of all the privileges of citizens, would indeed be a title to glory all our own. The scepter may pass from us. Unforeseen accidents may derange our most profound schemes of policy. Victory may be inconstant to our arms. But there are victories which are followed by no reverse. There is an empire exempt from all causes of decay. Those triumphs are the pacific triumphs of reason over barbarism; that empire is the imperishable empire of our arts and our morals, our literature and our laws. ${ }^{207}$

The similarity of purpose between two thinkers, each without much sympathy with the other, is clear. But, as John Clive has observed, the decisiveness of Macaulay's intervention in 1835 is not quite as straightforward as it is sometimes made to appear. The victory over those who favoured an educational policy pursued through local languages, which was signalled in Clive's famous minute to the Supreme Council of India, had been all but won before he wrote and addressed the Council on the side of English language education. GovernorGeneral Bentinck had indicated support. The policy had been proposed from the late eighteenth century as a means of undermining "the Hindu fabric of error" and propagating Christianity. As Grant had put it in 1797, "the English language... is a key which will open to them a world of new ideas, and

205 See K.D.M. Snell, Annals of the Laboring Poor (Cambridge: Cambridge University Press, 1985).

206 Mitchell Dean, The Constitution of Poverty: Toward a Genealogy of Liberal Governance (London: Routledge Publishing, 1991) at 96 ff.

207 Macaulay, Writings and Speeches, supra note 122 at 572. 
policy alone might have impelled us long since to put it into their hands." ${ }^{208}$ By 1823, Clive suggests, a number of trends were converging. A wealthy middle class of Hindu merchants who traded with the British favoured both British rule and the teaching of English language and culture. Given the impossibility of educating the mass of Indians within British India into the belief shared by British administrators and Hindu merchants in the inherent superiority of British culture, a process of downward diffusion from the colonial rulers and native elite was the generally agreed course of action by men like Charles Trevelyan, Macaulay's future brother-in-law, and William Bentinck, Governor of Madras earlier in the century, where Bentinck had been an energetic proponent of English language education. As Governor General from 1827, he was in thorough agreement with James Mill's view that Hindu and Muslim literature were "mischievous" and largely useless, ${ }^{209}$ and with Trevelyan's view that, only in English was a "tolerable education" to be obtained. Bentinck was, moreover, charged with the task of reducing Company costs, and enabling Indians to perform administrative tasks which would otherwise have to be undertaken by the higher-paid British, and which would assist in the endeavour to retrench Company expenditure.

Nevertheless, Macaulay's aim, one widely shared by the colonizers, was

$[\mathrm{t}] \mathrm{o}$ do our best to form a class who may be interpreters between us and the millions whom we govern; a class of persons, Indian in blood and colour, but English in taste, in opinions, in morals and in intellect. ${ }^{210}$

Stokes and a number of other writers, such as Pennycook and Viswanathan, have remarked that India provided a social laboratory from which, by virtue of the sovereignty exercised there, experiments could be attempted whose results might then find their way home. This educational invitation to collude in apparently universal values is a principal one. For Bentham and James Mill, law reform and codification were to be the primary tools in the civilizing mission. For Trevelyan and, to an increasing extent, Macaulay, beneath law and a condition of its acceptability and regular application, lay culture and its ability to draw a society otherwise diverse and unequal, together. ${ }^{211}$ But here we find a tension noticed by several authors (and, of course embodied in Macaulay himself). On the one hand, Trevelyan remarks that Macaulay's intervention, in marking the defeat of the Orientalists and commencing the diffusion or "filtration" of Englishness downward was "the turning point of (India's) intellectual progress." ${ }^{\prime 12}$

208 Quoted in Alastair Pennycook, English and the Discourses of Colonialism (London: Routledge Publishing, 1998) at 67.

209 Mill was unconvinced based on his observations of Ireland, that learning English would make Indians loyal British subjects, according to Clive supra note 147.

210 Ibid. at 376.

211 See Viswanathan, supra note 185 at 91; Stokes, supra note at 137 at 253 quotes evidence given in 1853 to a parliamentary committee concerning the importance of a "progressive education" in "attaching" the natives to their colonizers.

212 Trevelyan, supra note 129 at 486. 
We find J.T. Farich, ${ }^{213}$ quoted earlier, directly linking education and the utility to efficient government that would, he considered, serve by imparting English culture:

... the natives must either be kept down by a sense of our power, or they must willingly submit from a conviction that we are more wise, more just more humane and more anxious to improve their condition than any ruler they could have. ${ }^{214}$

Since the moral authority of an established Christian church was not a possibility in India, the greater wisdom of the colonizers was to be the heritage transmitted in English literature. Bearing in mind Pennycook's comment that "colonialism needs to be seen as a primary site of cultural production whose products have flowed back through the imperial system", we notice here an anticipation of Matthew Arnold's emphasis on producing governability among the "brawling" masses by spreading the "sweetness and light" of culture. ${ }^{215}$ But here is one of the tensions noticed by Viswanathan in his chapter, "The Failure of English". ${ }^{216}$ A previous chapter gives us Nobinchunder Dass and Mahendra Lal Basak-two students so "attached" to the colonizer that the first can see Indians as "natives" and the second is convinced that "the British government (of India) was a fair one promoting national prosperity and justice" which Indians, "still sleeping the sleep of death" could not themselves achieve. ${ }^{217}$ The "failure" is later explained as resulting from the "conflict between producing greater equality through the diffusion of western culture and western ideas and western knowledge and reproducing inequality through the occupational structure." 218

A second tension concerned the place of law in government. I suggested a divergence, or at the very least a significant difference in emphasis, between those who sought to govern principally by cultural assimilation through education - and Viswanathan argues that the latter had some successes until it collapsed under the weight of its own contradictions; and those for whom the law was the predominant tool. Roughly, the Utilitarians. As Dawson had suggested, and Lemmings reiterated, the two were of a pair whose conjunction recurred predictably enough in the UK and elsewhere. ${ }^{219}$ That the two were not divided is illustrated by the pedagogical overtones in this statement from James Fitzjames Stephen,

... our law is, in fact, the sum and substance of what we have to teach them. It is, so to speak, the gospel of the English, and it is a compulsory

213 See Viswanathan, supra note 185

214 J.T. Farich quoted in Viswanathan, supra note 185 at 113

215 Pennycook, supra note 208 at 132.

216 Gauri Viswanathan, Masks of Conquest: Literary Study and British Rule in India (New York: Columbia University Press, 1989).

217 Ibid. at 141.

218 Ibid. at 165.

219 See, in America, for example, the Canadian perspective of Wesley Pue, "A Profession in Defense of Capital?" (1992) 7 C.J.L.S. 267. 
gospel which admits of no dissent and no disobedience. ${ }^{220}$

As Stokes remarked, Bentham and his followers were more interested in authority than liberty. ${ }^{21}$ Stephen was a Hobbesian positivist, a utilitarian, utterly opposed to Indian self-rule on the ground that Britain, a "superior" and "belligerent" race, had obtained sovereignty in India by right of conquest, ${ }^{222}$ but equally, as a lawyer, committed to notions of impartiality and fair hearing. The tension generated by this stress on law as the basis of government was becoming evident in mid-century as the numbers of Indian students reading law increased. In 1866, Henry Maine expressed concern about the attraction of the "native bar" to the "young educated native". The bar offered both independence and a lucrative living, but carried also the danger of appealing to the Indian students' ability, delight, even, in "developing a grasp of fine detail and a remarkable capacity for subtle argument", without appreciating the breadth necessary for mature and rounded legal argument. ${ }^{223}$ This seems simply a prejudice arising from cultural antagonism and a resentment that from presumed "racial" inferiority should emerge litigators of ingenuity and effectiveness, taking on the English at their own game and often winning. The inherent tension was that articulate and intellectually and financially independent Indian professionals were able to use both the courts and the publicity they attracted to develop the cause of national independence. "Law was", as Cocks writes, "an obvious instrument of colonial politics," a situation not necessarily avoided by encouraging those Indians who could afford it to attend an Inn of Court in London.

\section{PATERNALISM AND THE PRODUCTION OF HARMONY}

If we bear in mind Pennycook's point about the imperial practices of government returning "home", we notice also that Charles Trevelyan, convinced of the connection quoted above, along with Sir Stafford Northcote; were charged by W.E. Gladstone, then Chancellor of the Exchequer in the Aberdeen Administration, with recommending British civil service reforms. One objective was bureaucratic efficiency. As a former Indian Civil Servant, an organization that excluded those "served" from its ranks - although an administrator of the Irish famine crisis "noted more for his logic than humanity"224 - Trevelyan, the senior figure, (Northcote seems to have been a man destined for obscurity) had a background in the paternal practices of the "servant", setting agendas for both political masters and the public ostensibly - no doubt conscientiously - being served. ${ }^{225}$

Gladstone's goal was that of "strengthening and multiplying the ties

220 R.C. J. Cocks, Sir Henry Maine: A Study in Victorian Jurisprudence (Cambridge: Cambridge University Press, 1988) at 87.

221 Stokes, supra note 141 at 234.

222 Ibid. at 288.

223 Cocks, supra note 220 at 90.

224 Roy Jenkins, Gladstone (London: Macmillan Publishers, 1995) at 165.

225 Ted Benton, "Realism, Power and Objective Interests" in Keith Graham ed., Contemporary Political Philosophy: Radical Studies (Cambridge: Cambridge University Press, 1982). 
between the higher classes and the possession of administrative power," ${ }^{\prime 226}$ in an era of threatening democracy. Robert Lowe, who had learned of the perils of democracy during his membership of the Assembly in New South Wales, urged the new service when it finally appeared some two decades later "to develop the kind of freemasonry that developed between the old boys of the great public schools and Oxbridge."227 Gladstone's concerns about the power of the people and the need to placate their aspirations for democracy whilst delaying real power until they could exercise their responsibility in a suitably educated way is, pure speculation, but remains consistent with the reluctance to relinquish imperial control elsewhere. The civil service changes were not fully implemented until Orders-in-Council were passed with Gladstone as Prime Minister in 1872 because mid-century Whigs and Whig-Liberals objected to what they correctly termed a paternalist "madarinate".

The new civil service was strictly hierarchical, with no possible promotion from the lower grades to the highest. The latter were initially accessible by examination in subjects - ancient Greek, classical Latin - available in the great public schools and Oxford and Cambridge. ${ }^{228}$ Benjamin Jowett, Fellow of All Souls, underwrote the laws of home and imperial law by his immense influence of placing his graduates in authority across a quarter of the globe, eventually providing an impetus to English literary studies by encouraging its importance in the Indian civil service curriculum to spread to Oxford and Cambridge. But we get ahead of ourselves and must return to Matthew Arnold, noticing, on the way T.B. Macaulay's change of heart on education.

Macaulay was asked by those who opposed government funding for elementary schooling for the poor, who would advocate, in effect, Ferguson's "mischievous interference" of the executive in the private decisions and lives lived in consequence of them. In an era of free trade, freedom of contract, and the freedom of the individual to do as he wished consistently with the same authority in every other-nobody would. However, who would doubt that the primary purpose of government is to secure the defence of the realm, and the personal security of its members and their property? As Macaulay states,

[t]his being admitted, can it be denied that the education of the common people is a most effectual means of securing our persons and our property? Let Adam Smith answer that question for me. His authority is entitled to peculiar respect because he extremely disliked busy, prying, interfering governments.. But he has expressly told us that a distinction is to be made between the education of the poor and the education of the rich. The education of the poor, he says, is a matter of deep concern to the commonwealth. ${ }^{229}$

Macaulay argues that, a magistrate must intervene to prevent the spread of contagious diseases. What greater "distemper" exists than an ignorant

226 E.J. Feuchtwanger, Gladstone (London: Allen Lane Publishers, 1975) at 92.

227 Peter Cowan, "The Origins of the Administrative Elite" (1987) 162 New Left Review 4, 32.

228 Ibid.

229 Macaulay, Writings and Speeches, supra note 122 at 734, 736. 
multitude? He paints a vivid picture of mob violence, a besieged Parliament, fleeing bishops, prisons opened, fires begun, "beautiful and costly machinery broken", crops burned; and then the consequences: "the wretches who were shot, who were hanged, who drank themselves to death in the rivers of gin which ran down Holburn Hill." The reasons for the disorder: "the ignorance of a population which had been suffered... to grow up as rude and stupid as any tribe of tattooed cannibals in New Zealand." The only alternative to the pacification of the population by weapons and grim punishments after the event, is education; "[t]o me it seems quite clear that whoever has a right to hang has a right to educate." ${ }^{.230}$ Posing the question this way, Macaulay positions his opponents - the churches for the most part - as seeing the state as simply "a great hangman."

Two decades after, Matthew Arnold, literary and social critic, schools inspector and later professor of poetry at Oxford, summarized the problem as he saw it, dividing British social order into the barbarians (the aristocracy), the middle class Philistines, and the populace, the latter of which, in its "sterner self... likes brawling, hustling and smashing; the lighter self, beer." ${ }^{232}$ Arnold sees the aristocracy as appropriate rulers in an earlier era as approaching the end of their power. They have given us, in their time, "staunch individualism" and the passion for asserting personal liberty. Looking back, if vaguely, into the issues dealt with in chapter one, he notices not only chivalry, but the accomplishments of the "politenesss... outward gifts and graces" without which a peaceful social order would have been impossible, as well as the "courage, high spirit and self confidence" without which the maintenance of that order would have been impossible." ${ }^{233}$ Looking forward, Arnold sees the middle class liberal dream of a joining together of the working and middle class from whose energy, as he wrote, the immense mercantile and unprecedented industrial wealth of the country, sprang.

For Arnold, what is missing is implied by the outdated nature of the constitution: "there is no adequate centre of authority - that is, as our culture teaches us to conceive of authority, of light.".234 In other words there is an absence of a strong state along Prussian lines. The outdatedness of aristocratic rule is nowhere so clearly evidenced, for Arnold, than in his "wondering whether there is anything so unintelligent, so unapt to perceive how the world is really going, as an ordinary young Englishman of our upper class". Arnold's natural disapprobation of European despotism is mitigated, not by what he so admires; education and the other state cultural apparatuses supported by, especially, Prussia, but by despotism's firm dealings with the "multitudes" $" 235$. At the same time, the middle class has failed to appreciate that, with the historical demise of a social order in which each knew and most accepted his or her place, all that remains for the British Constitution

230 Ibid. at 737 .

231 Ibid. at 739.

232 Mathew Arnold, Culture and Anarchy, ed. by Samuel Lipman (New Haven: Yale University Press, 1994) at 72 [Arnold, Culture].

233 Ibid. at 69.

234 Ibid. at 63.

235 Ibid. at 57. 
to rest upon is "our system of checks and balances and our notion of its being the great right of the Englishman to do as far as possible what he likes." ${ }^{236}$. However, in his imperial domains, things are different: "we can have no scruple at all about abridging, if necessary, a non-Englishman's assertion of personal liberty." ${ }^{237}$ In effect, then, disintegration can be avoided only by importing imperial practices into the domestic sphere. In such an imperial role, there seems less uncertainty. For John Stuart Mill,

$[\mathrm{t}]$ here are... conditions of society in which a vigorous despotism is in itself the best mode of government for training the people in what is specifically wanting to render them capable of a higher civilization. ${ }^{238}$

But for Mill and, for the most part, for Arnold, something less drastic was called for in Britain.

In Europe there is some realization that government can ultimately succeed only by accepting a duty to draw "the ordinary man's ordinary self" to a higher sense of right reason. However, the English Philistine dangerously does not appreciate that for the feudal order of the self knowing its place, there needs to be substituted a procedure for producing the best self that one can be. If licensed victuallers or commercial travellers have an ideal of education, Arnold suggests, it would be of schools for licensed grocers or travelling salesmen, although

[r]ight reason would suggest that to have a sheer school for Licensed Victuallers' children or a sheer school for commercial travellers' children and to bring them up, not only at home, but at school, too, in a kind of odour of licensed victualism or bagmanism is not a wise training to give these children. And in Germany, I have said, the action of national guides or governors is to suggest and provide a better. ${ }^{239}$

In Friendship's Garland (published in 1871), Arnold's narrative takes on a more dramatic character, when the narrator confronts an imaginary Prussian professor, Arminius, with an account of the education of "Businessman Bottles, a Radical of the first water; quite one of the Manchester school." Since the English state leaves not only the provision but also the quality and purpose of education entirely to the market, Mr. Bottles' parents were able to secure for him instruction of a kind perfectly focused on his future avocation in the hands of Dr. Silverpump in an academy in Peckham. His educational philosophy,

[a]s I have heard his pupil Bottles put it in his expansive moments after dinner: 'original man, Silverpump. Fine mind! Fine system!

236 Ibid. at 50 .

237 Ibid. at 54.

238 John Stuart Mill, Considerations on Representative Government (New York: Prometheus Books, 1991) at 345-346

239 Arnold, Culture, supra note 232 at 80. 


\begin{abstract}
None of your antiquated rubbish - all practical work - latest discoveries in science - mind constantly excited - lots of interesting experiments - lights of all colours - fizz! Fizz! Bang! Bang! That's what I call forming a man. ${ }^{240}$
\end{abstract}

Bottles made, the narrator explains, a large fortune, but as to the kind of man or the kind of mind... at which point Arminius interjects, "you need not go on; I know what that man's mind is well enough."

What, then, is to be done? The Populace rather than the Barbarians, whose power is rapidly waning, are at the gate. After the violence of the Reform Bill riots in Hyde Park, Arnold was convinced that more than mere mediocrity was threatened, but civilized order itself. Baldick quotes Arnold's initial reaction to these from the first edition of Culture and Anarchy:

[a]s for rioting, the old Roman way of dealing with that is always the right one; flog the rank and file and fling the ringleaders from the Tarpeian Rock! And this opinion we can never forsake, however our Liberal friends may think a little rioting, and what they call popular demonstrations, useful sometimes to their own interests.

"This indiscretion", Baldick writes, "was suppressed after the first edition."241 This looks like a return to a social theory, labeled by Arnold, that is, Hebraic, a reliance on authority and rules. In more discreet moments, what Arnold contemporary proponents and later proponents of education for adults and children expected was an agency for producing harmony out of apparently irreconcilable difference. The subject of English literature would assimilate the classes, women and Indians, and induct children. Its example, through demonstration of the national heritage, would guide its pupils toward their best selves as English subjects. ${ }^{242}$ But if this is the vehicle, who is qualified to drive it? There are, outside the turmoil of Barbarians, Philistines and Populace, notably, "aliens", "persons who are mainly led, not by their class spirit, but by a general bumane spirit, by the love of human perfection." 243 They provide "a source of authority" facilitating the production of "our best self". ${ }^{244}$ Arnold is clearer in other texts, declaring that the "middle classes" have the power in the mid-Victorian era of working class male enfranchisement, "to make the condition that this government shall be one their own adoption, one that they can trust." 245

The idea of curiosity as a virtue needs to be recovered for English culture in order that here, too, we should strive "to know the best that is known and thought in the world, irrespective of practice, politics and everything of the kind." 246 Elsewhere, Arnold sees "the critical spirit", armed with "a

240 Quoted in Herbert Paul, Matthew Arnold (London: Macmillan Publishers, 1902) at 128-129.

241 Chris Baldick, The Social Mission of English Criticism (Oxford: Oxford University Press, 1983) at 107.

242 Ibid. at 82

243 Arnold, Culture, supra note 232 at 73.

244 Ibid. at 74.

245 Matthew Arnold, Mixed Essays (London: Smith Elder and Company, 1879) at 41 [Arnold, Essays].

246 Matthew Arnold, Essays in Criticism, First Series (London: Macmillan Publishers, 1921) at 16. 
knowledge of Greek, Roman and Eastern antiquity" and the appreciation of "Europe as being for intellectual and spiritual purposes one great confederation" beckoning the population as a whole to a "promised land", one nourished by cultural creativity in life and literature. This cultural vision of social engineering, which Arnold sometimes refers to as "Hellenism" is contrasted to what he terms the "Hebraic" approach: ${ }^{247}$ the reliance upon rules to produce and maintain social change, an approach which resembles FR Leavis's "technologico-Benthamism". Happiness is not the adherence to good laws, those which seek to enable us to be happy, but the desire to become perfect, which we shall never achieve. Instead, we shall "die in the wilderness," ${ }^{248}$ but, having recognized perfection, we can make a claim to progress and the "esteem of posterity".

\section{CONCLUSION}

In the end a kind of Whiggery prevailed. The Jeffersonian "agreement of the people", that would have carried it from benign paternalism to democracy in the maintenance of order, was never developed. Its "Hellenism", as Arnold would have put it, remained recognizably paternalistic and therefore resented and ultimately vulnerable to the Thatcherites. Its legalism, more weakly inherited from the Benthamites, was less convincing to its ruling classes. Neither Portuguese, nor Spanish nor French imperialists would have tolerated Gandhi. Elsewhere, perhaps, Winston Churchill in the 1930s would have become a Peron. Where else could an outgoing victorious leader have commented in 1946 of his successor, that an empty car drew up outside 10 Downing Street, from which stepped Clement Atlee?

But I have noted a reversion ${ }^{249}$ to insistences on political sovereignty as embodied in a particular approach to legality and its attributes. This reunion clearly emanates from elsewhere. Neither is self-explanatory. They need to be set in context, which is what I tried to do in referring to the anxieties that seem to have led to the necessity for a sudden imagining of the Atlantic empire as a unitary state under Westminster. It is important, whilst schematizing, not to oversimplify. Even law and order Tories, like Castlereagh and Wellington, looked with some distaste and not a little superiority at the doctrines of their former allies in the French wars, the Czar and the emperors of Prussia and Austria. Even a man who tramped miserable industrial slums and campaigned for the education of the poor, could be provoked by London riots into intemperate remarks about law and order more in keeping with the views of General Heynau, who was mobbed by Barclay and Perkins draymen on his visit to London in 1850, for his brutal repression of the Hungarians in $1848 .^{250}$

The situation is complicated by the authoritarian turn taken by contemporary advocates of cultural assimilationism - a task for another time. But I wish to stress the important differences between the social theories

247 Arnold, Culture, supra note 232 at $86 \mathrm{ff}$.

248 Arnold, Essays, supra note 245 at 41.

249 Jean Laplanche and J.B. Pontalis, The Language of Psycho-Analysis, trans. by D. Nicholson-Smith (New York: Norton Publishers, 1973) at 78, 281.

250 R.J. Evans, The Victorian Age 1815-1914 (London: Edward Arnold Publishers, 1950) at 132. 
that follow a path traced by Bentham, Austin, Stephen and their successors, and those of the paternalist reformers, a sometimes compatible, band such as Leavis and the educational and welfare reformers like Beveridge, Butler, Keynes and others. The work of the English, the Scots and the Americans, I argue, following Hannah Arendt's work, demonstrates that He (and Hobbes' "mortal god" is very much positioned as a $\mathrm{He}$ ) is dispensable in the production of order, and produces, contrary to Hobbesian hopes, a murderously, ultimately suicidal, potential for humanity... The message of my text is that some order must be accepted and imposed, but that it must be imposed plurally, transiently and tolerantly. The cultural analysis of authority avoids many of the dangers inspired by both legal positivist obsessions with sovereignty and the metatheoretical responses in much of contemporary jurisprudence, which emerges from cultures with little or no experience of, or learning from, colonialism. Legal education might be a beneficiary of such a program. 